Universidade de Brasília

Instituto de Relações Internacionais

Programa de Pós-Graduação Lato Sensu em Relações Internacionais

Bruna Duarte Habka

O CASO DO ALGODÃO NA OMC (2002-2010)

Brasília

2010 
Bruna Duarte Habka

\title{
O CASO DO ALGODÃO NA OMC (2002-2010)
}

\author{
Trabalho de Conclusão de Curso de Relações \\ Internacionais para o Instituto de Relações \\ Internacionais da Universidade de Brasília, \\ apresentado como requisito parcial à obtenção do \\ título de Especialista em Relações Internacionais.
}

Orientadora: Prof ${ }^{a}$ Dr $^{\mathrm{a}}$ Norma Breda dos Santos 


\section{FICHA CATALOGRÁFICA}

Habka, Bruna Duarte

O caso do algodão na OMC (2002-2010)/ Bruna Duarte Habka: Orientadora Prof ${ }^{\mathrm{a}}$ Dr $^{\mathrm{a}}$ Norma Breda dos Santos - Brasília, 2010.

$70 \mathrm{p}$.

Trabalho de Conclusão de Curso. Instituto de Relações Internacionais/ Universidade de Brasília. Curso de Especialização em Relações Internacionais.

1. OMC 2. Política Externa Brasileira 3. Algodão 


\section{AGRADECIMENTOS}

À Professora Norma Breda dos Santos, pelo constante apoio à pesquisa e pelos ensinamentos adquiridos.

Aos meus pais, pelo eterno incentivo, pelo amor e pela participação em meus objetivos.

À colega Marcella Campos, pelo intercâmbio de experiência.

À Associação Brasileira dos Produtores de Algodão (ABRAPA), pelo pronto fornecimento de informações.

A todos aqueles que contribuíram, de certa forma, para a consecução desse trabalho. 
“A opinião pública está do nosso lado, a lei e o povo estão do nosso lado. As grandes organizações não-governamentais, as grandes multinacionais reconhecem que o sistema é distorcido e gera transferência de renda de país pobre para país rico”.

(Luiz Fernando Furlan, em 2004, acerca do painel do algodão) 


\section{RESUMO}

O objetivo desse trabalho é estudar o caso do algodão na Organização Mundial do Comércio. Para isso, analisou-se a participação de atores não-governamentais, os quais foram determinantes para levar o caso adiante, além dos aspectos técnicos que justificaram o pleito brasileiro e embasaram o pedido. Utilizou-se, assim, a metodologia de estudo de caso. Concluiu-se que há certa democratização da política externa brasileira, haja vista a indispensável participação de atores não-estatais no caso, porém a capacidade destes de influenciar o Estado depende de sua própria capacidade de organização e articulação.

Palavras-chave: OMC, política externa brasileira, grupos de interesse, algodão. 


\begin{abstract}
The aim of this work is to study the World Trade Organization cotton case. For this, we analyzed the participation of non-governmental actors, who were instrumental in bringing the case forward, beyond the technical aspects that served as the basis of the request. Therefore, we used the methodology of case study. It was concluded that there is a certain democratization of Brazilian foreign policy, given the essential participation of non-state actors in the case, but their ability to influence the state depends on their own organizational skills and articulation.
\end{abstract}

Keywords: WTO, Brazilian foreign policy, interest groups, cotton. 


\section{SUMÁRIO}

INTRODUÇÃO ................................................................................................................... 8

1. O SISTEMA MULTILATERAL DE COMÉRCIO ............................................ 13

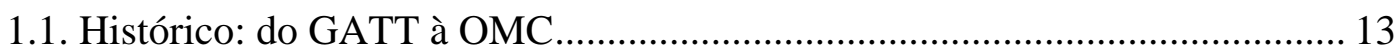

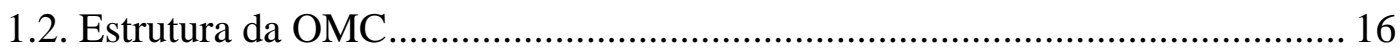

1.3. A Conferência de Seattle e a Rodada Doha....................................................... 17

1.4. O Sistema de Solução de Controvérsias da OMC ........................................... 21

2. O CONTENCIOSO DO ALGODÃO ................................................................. 28

2.1. O Acordo sobre Agricultura e o Acordo sobre Subsídios e Medidas

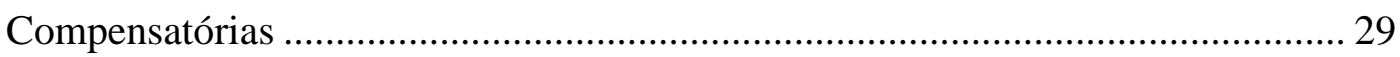

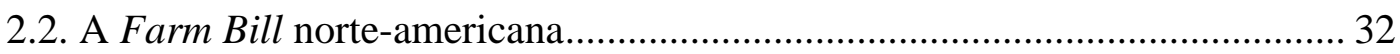

2.3. O Caso do Algodão na OMC (DS 267).......................................................... 34

2.3.1. A Cláusula de Paz não impede a ação ........................................................ 35

2.3.2. Os pagamentos diretos não são subsídios contidos na Caixa Verde ........ 36

2.3.3. O programa Step 2 é ilegal......................................................................... 36

2.3.4. Os programas de garantia à exportação não estão em conformidade com

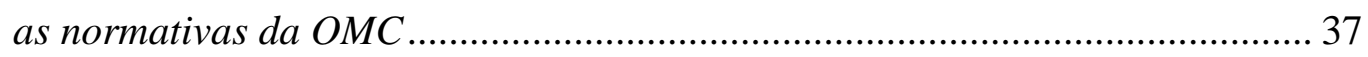

2.3.5. Os subsídios ao algodão causaram sérios danos ao Brasil ...................... 37

2.3.6. Implementação dos relatórios do DS 267 e desdobramentos do caso ..... 38

3. PROCESSO DECISÓRIO EM POLÍTICA EXTERNA: OS ATORES DO

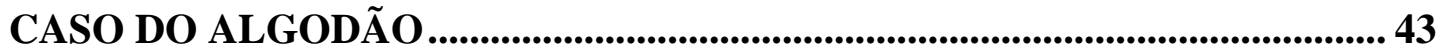

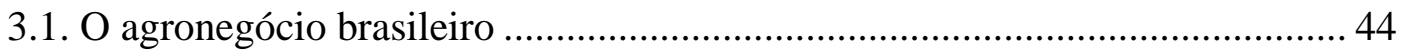

3.2. A primeira tentativa e a ABRAPA …………………………..................... 45

3.3. O Ministério da Agricultura .............................................................................. 46

3.4. A articulação entre a esfera pública e a privada ................................................. 47

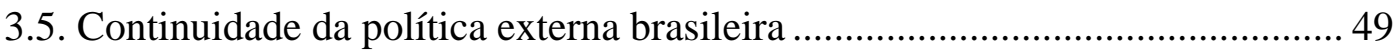

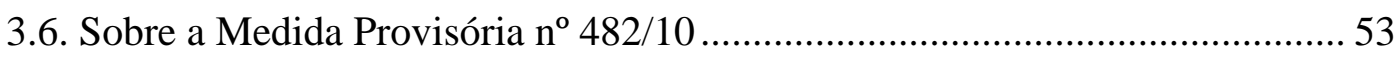

3.7. Democratização e política externa..................................................................... 54

3.7.1. A participação das organizações não-governamentais................................ 54

3.7.2. Aumento da democratização?.................................................................. 56

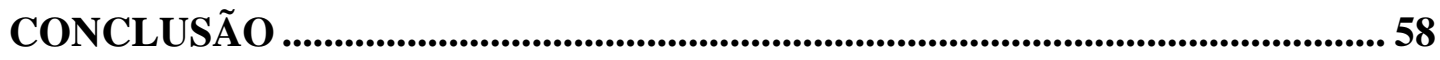

REFERÊNCIAS BIBLIOGRÁFICAS...............................................................61

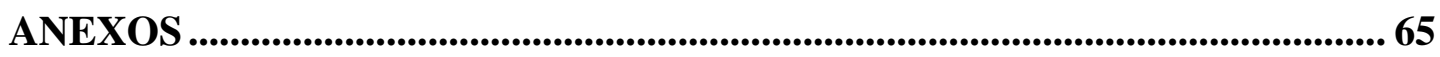




\section{INTRODUÇÃO}

O Brasil é um dos países em desenvolvimento que mais se vale do Órgão de Solução de Controvérsias (OSC) da Organização Mundial do Comércio (OMC). No final de 2002, o Brasil tinha 22 reclamações no órgão, das quais 8 eram contra os Estados Unidos (EUA). Em 2009¹, havia 24 reclamações, das quais 10 contra os EUA. Destas, pelo menos cinco decisões já deram ganho de causa ao Brasil - o caso da gasolina (o primeiro painel criado pela OMC), o das salvaguardas à importação de produtos siderúrgicos, o de direitos compensatórios sobre produtos de aço-carbono brasileiros e os contenciosos do algodão e do código norte-americano das patentes. Por seu lado, até março de $2010^{2}$, os EUA apresentaram quatro reclamações contra o Brasil: medidas que afetavam a proteção das patentes no Brasil, as relativas a preços mínimos na importação e duas reclamações quanto a medidas que afetavam o comércio e o investimento no setor de automotivos. Nenhuma delas, entretanto, foi decidida contra os interesses brasileiros, tendo as partes alcançado solução mutuamente satisfatória.

No que concerne às reclamações brasileiras, é importante observar que os subsídios agrícolas continuam sendo um ponto sensível na relação entre países desenvolvidos e países em desenvolvimento, no âmbito da OMC. Extensamente praticados pelos Estados Unidos e pela União Européia, os subsídios prejudicam muito países em desenvolvimento, que são, via de regra, bastante competitivos no setor agrícola. A atual Rodada de Doha, iniciada em 2001, só faz demonstrá-lo. Apesar de esforços envidados por Pascal Lamy, Diretor-Geral da OMC, a conclusão da rodada permanece um grande ponto de interrogação. Em 2008, a rodada foi, mais uma vez, bloqueada com a insistência dos países desenvolvidos sobre a necessidade de avançar na liberalização de produtos industrializados, enquanto os países em desenvolvimento não viam, de modo geral, um movimento significativo com relação à diminuição dos subsídios naqueles países. Esse, inclusive, foi o motivo pelo qual o

\footnotetext{
${ }^{1}$ Ver sítio da OMC: DS 4, DS 217, DS 218, DS224, DS239, DS 250, DS 259, DS 267, DS 365 e DS 382.

${ }^{2}$ Ver sítio da OMC: DS 52, DS 65, DS 197 e DS 199.
} 
G-20 ${ }^{3}$ foi criado na V Conferência Ministerial, em Cancun, em 2003. A atuação do grupo centra-se na temática da agricultura, e os países do G-20 representam quase $60 \%$ da população mundial e $70 \%$ da população rural (VIZENTINI, 2006). A proposta apresentada por Lamy, em 2008, continha 20 tópicos. Desses, 18 atingiram o consenso. $\mathrm{O} 19^{\circ}$ gerou os debates do encontro em 2008 - trata-se de um dispositivo para a proteção de produtores agrícolas, em países em desenvolvimento, quando houvesse grande aumento de importações - e o $20^{\circ}$, acerca do algodão, não foi alcançado (THE ECONOMIST, 2008).

O painel do algodão ${ }^{4}$ faz parte dessa difícil dimensão da história do sistema multilateral de comércio. Iniciado em 2003, com a reclamação brasileira contra os subsídios concedidos pelo governo norte-americano aos seus produtores de algodão, o propósito do painel era analisar as distorções causadas pela Lei Agrícola (Farm Bill) aos preços internacionais do algodão. Em 2004, o painel concluiu que os subsídios ao algodão, de fato, causaram prejuízos aos interesses brasileiros e que créditos à exportação concedidos pelos EUA eram incompatíveis com o Acordo sobre Agricultura e com o Acordo sobre Subsídios e Medidas Compensatórias da OMC.

Os EUA apelaram dessa decisão e, em junho de 2008, o Órgão de Apelações (OA), no entanto, manteve o relatório do painel, que requeria que os EUA modificassem sua política de subsídios. O Brasil solicitou, então, à OMC uma autorização para aplicar medidas compensatórias aos EUA no valor de US\$ 2,5 bilhões pelos prejuízos provocados pelos subsídios norte-americanos à produção nacional, entre 1999 e 2002. Em 2009, estava em negociação a forma de aplicar a decisão, que poderia se uma retaliação cruzada - isto é, aplicada em atividades diversas da que originou a demanda na OMC - e em que setores da economia norteamericana. Houve, no governo brasileiro, a defesa de que a compensação deveria ser na área de propriedade intelectual, justamente por ser um setor sensível aos Estados Unidos. Os produtores de algodão brasileiros, contudo, querem ser beneficiados com

${ }^{3}$ Alguns países do G20: além do Brasil, que exerce liderança no grupo, Índia, África do Sul, Argentina, Bolívia Chile, China, Cuba, Egito, Filipinas, México, Indonésia, Nigéria, Paquistão, Tanzânia, Paraguai, Venezuela e Zimbábue.

${ }^{4}$ Numerado na OMC como DS (Dispute Settlement) 267. 
a medida retaliatória, haja vista terem despendido recursos financeiros com a defesa brasileira perante a OMC. Os EUA, no entanto, discordaram dessa autorização à retaliação cruzada e solicitaram, em 2009, a revisão da possibilidade de haver esse tipo de cross-retaliation. Assim, em 31 de agosto de 2009, houve posicionamento final da OMC, que, apesar de manter o direito brasileiro de obter a compensação, mitigou o valor desejado para cerca de US\$ 830 milhões.

Segundo Welber Barral, a decisão do painel deve ser considerada histórica devido aos seguintes fatores:

\begin{abstract}
“a correta interpretação dos acordos agrícolas, um produto sensível para vários países em desenvolvimento, o montante indecente de subsídios concedidos por países desenvolvidos, a vitória do Brasil num tema que lhe é caro. A relevância da decisão também se refere ao momento histórico (meados de uma nova rodada de negociações), o que assevera a legitimidade das reclamações constantes do Brasil e dos demais países exportadores de produtos agrícolas”(2007).
\end{abstract}

Este trabalho objetiva responder às seguintes perguntas: a participação de atores não-governamentais, no painel do algodão, foi determinante para a vitória brasileira? Em caso positivo, tal participação significaria maior democratização da política externa brasileira?

Sabe-se que houve, no caso, relevante participação da organização nãogovernamental OXFAM, com estudos sobre os prejuízos causados pelos subsídios norte-americanos aos países exportadores de algodão, mormente aos países africanos $^{5}$, como Benin, Burkina Faso, Chad e Mali. No Brasil, a Associação Brasileira dos Produtores de Algodão (ABRAPA) desempenhou papel importante, ao financiar o contencioso do algodão, além de atuar como grupo de pressão, junto à

\footnotetext{
5 “O Brasil recebeu, com satisfação, o relatório do Órgão de Apelação da OMC sobre subsídios norteamericanos à produção e exportação de algodão. O documento, circulado hoje em Genebra, deverá ser adotado pelo Órgão de Solução de Controvérsias da Organização em até 30 dias, juntamente com o relatório do painel. [...] A manifestação do Órgão de Apelação não favorece apenas o Brasil. Ela empresta renovada força jurídica aos pleitos dos países africanos produtores de algodão, para os quais os subsídios influenciaram dramaticamente os números relativos à pobreza. A sentença esclarece, igualmente, o conteúdo e o alcance de importantes disciplinas multilaterais sobre o comércio agrícola, em sua maioria examinadas pela primeira vez no presente caso. Reforça, por fim, a legitimidade dos países, grupos e cidadãos que defendem o fim das distorções no comércio agrícola mundial.” (MRE. Nota à imprensa, 2005; grifos nossos)
} 
coalizão da bancada ruralista do Congresso brasileiro, a fim de que o Ministério das Relações Exteriores (MRE) solicitasse a abertura do painel ${ }^{6}$.

Marcelo Fernandes de Oliveira, em artigo que analisa o painel do algodão, informa que a formulação da estratégia brasileira teve início na sociedade civil, principalmente com a participação de Pedro de Camargo Neto, da Sociedade Rural Brasileira (SRB) e que o Itamaraty, inicialmente, foi contra a instauração do contencioso na OMC, porque não queria ir de encontro aos interesses estadounidenses - mormente na segunda metade da década de 1990, em que o bom entendimento entre Clinton e Fernando Henrique Cardoso prevalecia. Em 2001, esse quadro sofreu alteração com a posse de George W. Bush como presidente dos EUA e a posse de Celso Lafer como Ministro das Relações Exteriores no Brasil. O Ministério da Agricultura e o MRE passaram a convergir para, cooperando com o setor privado, formularem a atuação na OMC. (OLIVEIRA, 2007)

Dessa forma, será utilizada a metodologia de estudo de caso com ênfase na participação dos grupos de interesse que atuaram no contencioso do algodão. Para isso, valemo-nos do trabalho de Cristopher Hill (2003), para quem as teorias realistas e neorealistas são insuficientes para explicar a dinâmica da política exterior em que vários grupos atuam, porquanto o Estado é visto como ator unitário, o que é incompatível com a diversidade de atores que atuam no processo decisório político. O autor, no entanto, leva em consideração as assimetrias de poder no âmbito internacional, visualizando que alguns atores possuem mais capacidade e liberdade de atuação internacional.

Este trabalho está estruturado em 3 (três) capítulos. O primeiro tratará da OMC, seu histórico, a transição do General Agreement on Tariffs and Trade (GATT)-1947 para a institucionalização de uma organização internacional. Também analisará a estrutura normativa da OMC e o funcionamento de seu Organismo de Solução de Controvérsias.

\footnotetext{
6 "No campo internacional, atuamos em várias frentes. Lutamos junto a organismos multilaterais, como a OMC, por melhores condições de competitividade para o algodão brasileiro; abrimos mercados e trocamos conhecimentos com outros países para aumentar nossa produção e produtividade.” (ABRAPA, 2007)
} 
O segundo capítulo estruturará as fases do contencioso do algodão, a partir de fontes primárias, adquiridas no sítio da OMC na internet. Deve ser ressaltado, assim, que todos os pedidos feitos por Brasil e Estados Unidos no caso, além das decisões tomadas pela OMC, estão disponíveis no sítio da organização. Tal capítulo, então, é relevante para compreender a dimensão exata do litígio e os argumentos que embasaram o pedido formulado pelo Brasil.

O terceiro capítulo tecerá a análise do caso, condensando as informações do segundo capítulo com as adquiridas na literatura disponível acerca da participação não-governamental no caso. Nessa parte do trabalho é que será visualizado o efetivo envolvimento dos grupos de interesse com o sucesso brasileiro na OMC, de forma a responder às perguntas feitas nessa introdução. Repita-se: a participação de atores não-governamentais, no painel do algodão, foi determinante para a vitória brasileira? Se o foi, tal participação significaria maior democratização da política externa brasileira? Veremos. 


\section{O SISTEMA MULTILATERAL DE COMÉRCIO}

John H. Jackson (1992, p. 218), ao analisar a criação da Organização Mundial de Comércio (OMC), compara-a à plataforma comum de trabalho entre computadores com sistemas operacionais diferentes. Celso Lafer utiliza-se dessa metáfora e conclui que, tal qual a plataforma que conecta sistemas operacionais, é possível afirmar que o marco institucional representado pela OMC serve para “conectar economias nacionais distintas num mercado globalizado” (LAFER, 1998, p. 24).

O General Agreement on Tariffs and Trade (GATT), de 1947, foi concebido meramente como um acordo entre partes, não possuindo a natureza de organização internacional como a OMC possui. Tal característica garantiu-lhe a alcunha de GATT a la carte (PETERSMAN, 1997), uma vez que as partes poderiam escolher a que acordos aderir, além de gerar uma série de discrepâncias - Petersman (1997, p. 52) cita, como um dos exemplos, o fato de que os preços mínimos prescritos pela Rodada de Tóquio não tinham amparo legal nas normas gerais do GATT, além do fato de o Conselho do GATT não ter autoridade para interpretar acordos da mesma rodada de negociações. Divergia, assim, muito da sistemática da OMC, cuja Conferência Ministerial tem autoridade para tomar decisões em todas as matérias de qualquer acordo multilateral de comércio ${ }^{7}$. Veremos a seguir o histórico que levou ao surgimento da OMC, em 1995.

\subsection{Histórico: do GATT à OMC}

O ano de 2009 marca os 20 anos da queda do muro de Berlim, ocorrida em novembro de 1989 - episódio que simbolizou o término da Guerra Fria. Em razão de a polaridade do modelo bipolar não mais subsistir, os Estados Unidos (EUA) embora emergissem como potência hegemônica na década de 1990 -, no que tange ao comércio internacional, o país dividia a liderança com outras nações relevantes, como o Japão e a União Europeia. Desse modo, os EUA não eram mais “árbitros das regras do comércio” (THORSTENSEN, 2001, p. 22), o que gerou a necessidade de

\footnotetext{
${ }^{7}$ Vide artigo IV: 1 do Acordo da OMC.
} 
uma instituição que viesse a arbitrar o comércio internacional de forma clara, capaz de dirimir as contendas entre as potências comerciais.

Pode-se afirmar, no entanto, que a OMC tem suas origens remotas no fim da Segunda Guerra Mundial. Em 1944, com o encontro de Bretton Woods, os aliados tinham o objetivo de criar três instituições que auxiliariam no processo de reconstrução da economia mundial: o Fundo Monetário Internacional (FMI), o Banco Internacional para a Reconstrução e Desenvolvimento (BIRD ou Banco Mundial) e a Organização Internacional do Comércio (OIC).

A função primária do FMI seria a defesa do sistema monetário internacional, o que significa a manutenção da estabilidade das taxas de câmbio e a ajuda a países com problemas no balanço de pagamentos. O BIRD deveria investir em programas que auxiliassem na reconstrução de países afetados pela guerra. A OIC teria a função de coordenar a negociações para um novo regime multilateral de comércio, pautado em princípios liberais.

Embora o FMI e o BIRD tenham sido efetivamente constituídos, a OIC não o foi, porque a Carta de Havana, instrumento que a criava, jamais foi ratificada pelos EUA - havia naquele país o medo de que a instituição poderia limitar a soberania norte-americana em assuntos de comércio internacional. Além disso, a comunidade internacional também divergia de alguns pontos da Carta, tais como “a abrangência do poder da nova organização”, as práticas comercias que deveriam ser abolidas, os níveis em que deveriam ser diminuídas as barreiras comerciais e o horizonte temporal para a Carta entrar em vigor (SATO, 2006, p. 138).

Dessa forma, o GATT foi negociado como acordo provisório, que permitiria a liberalização gradual do comércio. Dizia respeito a uma parte específica do comércio internacional: tarifas. Negociações no âmbito do GATT inclusive, como em Genebra (1947) e Annecy (1949), demonstraram que seria difícil outra atitude quanto ao comércio internacional, que não negociar reduções tarifárias caso a caso (GATT a la carte). Por isso, o GATT subsistiu por tanto tempo, transformando-se, 
na prática, em espécie de organismo internacional, coordenando as regras de comércio até o advento da OMC.

Houve oito rodadas de negociações no âmbito do GATT: Genebra (1947), Annecy (1949), Torquay (1951), Genebra (1956), Dillon (1960-61), Kennedy (196467), Tóquio (1973-79) e Uruguai (1986-94). Números fornecidos pela OMC demonstram a crescente importância do comércio internacional: enquanto, em 1947, havia 23 participantes e a movimentação de cerca de US\$ 10 bilhões, em 1994, já havia um total de 123 participantes e a movimentação de US\$ 3,7 trilhões.

De acordo com Vera Thorstensen (2001, p. 30), as seis primeiras rodadas tinham por objetivo a diminuição de tarifas, com base em negociações que fornecessem isenções tarifárias recíprocas. A autora apresenta o dado de que, em 1947, a média tarifária era de 40\%, e, em 1994, tal média passou a ser de 5\%. Dessa forma, pode-se afirmar que o GATT teve êxito nas propostas lançadas em suas primeiras rodadas de negociação.

A Rodada Tóquio, diferentemente das anteriores, aprimorou as regras do GATT com a produção de nove acordos: barreiras técnicas, subsídios, antiduping, valoração aduaneira, licenças de importação, compras governamentais, comércio de aeronaves, acordo sobre carne bovina e acordo sobre produtos lácteos (THORSTENSEN, 2001, p. 31).

A Rodada Uruguai foi mais ambiciosa, haja vista a necessidade de se introduzirem novos setores às negociações comerciais, tais como agricultura e têxteis, além de incluir em seu escopo as áreas de serviços, investimentos e propriedade intelectual $^{8}$. Embora tenha sido criada para durar três anos apenas, foi iniciada em 1986, em Punta Del Este, e concluída somente em 1994, em Marraqueche (Marrocos). Welber Barral (2002, p. 14) informa que, quando a

\footnotetext{
${ }^{8}$ Vide anexo 1, ao final deste trabalho, o qual apresenta a estrutura dos acordos negociados na Rodada Uruguai.
} 
Rodada Uruguai terminou, os textos negociados e seus anexos totalizavam cerca de 26.000 páginas de regras que tratavam de quase todo o comércio mundial. ${ }^{9}$

A Organização Mundial do Comércio, assim, foi produto da evolução do comércio internacional e da necessidade de harmonizar a divisão surgida entre países desenvolvidos e países em desenvolvimento. Os primeiros queriam a regulação de matérias como serviços e propriedade intelectual; os segundos, a inclusão do setor agrícola e de têxteis.

Embora tenha havido muitos impasses durante a Rodada Uruguai, a Comunidade Europeia (CE) e os Estados Unidos, em 1992, chegaram ao Acordo de Blair House, sobre a questão agrícola. Em julho de 1993, o Quad, integrado por EUA, Canadá, CE e Japão negociaram, no âmbito do G7, um modo para avançar as negociações da rodada iniciada em Punta Del Este. Dessa forma, foi possível concluir a rodada, e a OMC começou a funcionar, em janeiro de 1995, apresentando os seguintes princípios: nação mais favorecida - evitar a diferenciação entre parceiros comerciais -, tratamento nacional - dar aos produtos estrangeiros o mesmo tratamento dado aos seus próprios produtos -, liberalização do comércio, previsibilidade e transparência, justa concorrência e o incentivo ao desenvolvimento sustentável. ${ }^{10}$

\subsection{Estrutura da OMC}

A OMC é constituída por uma Conferência Ministerial (Ministerial Conference), que tem, abaixo dela, um Órgão de Exame de Política Comercial (Trade Policy Review Body), um Órgão de Solução de Controvérsias (Dispute Settlement Body) e um Conselho Geral (General Council). Sob este último, há três Conselhos: o de comércio de mercadorias (Council for Trade in Goods), o de comércio de serviços (Council for Trade in Services) e o sobre aspectos de direito de

\footnotetext{
${ }^{9}$ No Brasil, o decreto $n^{\circ}$ 1.355/94 é o documento legal que promulga os Acordos da Rodada Uruguai. ${ }^{10}$ A OMC não fala propriamente em desenvolvimento sustentável, mas em "encouraging development and economic reform", o que, no Brasil, foi interpretado como desenvolvimento sustentável. Disponível em: <http://www.wto.org/english/thewto_e/whatis_e/tif_e/understanding_e.pdf> Acesso em Nov/2009.
} 
propriedade intelectual (Council for Trade-Related Aspects of Intellectual Property Rights ${ }^{11}$. O sistema de solução de controvérsias da OMC tem especial relevância para este trabalho e, por isso, será visto de forma mais detalhada no item 1.4.

Cabe ressaltar que, atualmente, a agenda da Rodada Doha de Desenvolvimento (estudada no item 1.3) submete-se, também, diretamente ao Conselho Geral, por seu Comitê de Negociações Comerciais (Trade Negotiations Committee), o qual é responsável por grupos negociadores quanto a acesso a mercados (market access), facilitação do comércio (trade facilitation) e regras (rules). A Rodada Doha também tem sessões especiais no Conselho de Serviços, no Conselho de Propriedade Intelectual, no Órgão de Solução de Controvérsias, no Comitê de Agricultura (e, frise-se, no Subcomitê do Algodão), no Comitê para Comércio e Desenvolvimento e, por fim, no Comitê para Comércio e Meio Ambiente.

Importante mencionar, ainda sobre a estrutura da OMC, que o termo GATT1994 se refere ao arcabouço do GATT-1947 e a todos os instrumentos que entraram em vigor em 1995, incluindo, assim, concessões tarifárias, protocolos de acesso de novos membros, decisões de derrogação de obrigações concedidas, seis entendimentos negociados dentro da área de comércio de bens e o Protocolo de Marraqueche, que estabelece os prazos para as reduções tarifárias (THORSTENSEN, 2001, p. 41).

\subsection{A Conferência de Seattle e a Rodada Doha}

Era previsto que, em Seattle, em 1999, deveria ser lançada nova rodada de negociações, em razão, sobretudo, da constatação feita pelos países em desenvolvimento de que a liberalização não os havia beneficiado. Além disso, houve a percepção por parte dos países hegemônicos de que, apesar da diminuição das tarifas, a criação de barreiras não-tarifárias, calcadas na criatividade para proteger-se certo mercado, haviam se proliferado.

\footnotetext{
${ }^{11}$ Vide Anexo 2, ao final desse trabalho, o qual apresenta quadro da estrutura da OMC.
} 
Seattle, no entanto, fracassou em coordenar a formação de uma pauta para negociações. Para Barral (2002, p. 19), o problema da conferência na cidade norteamericana foi não apenas o papel das organizações não-governamentais (ONGs) que foram contra o aprofundamento das normativas da OMC -, mas também o fato de não haver consenso, em 1999, sobre a indicação do Diretor-Geral, o que comprometeu a organização da conferência e não tornou possível um texto definitivo a ser debatido pelos negociadores. O autor cita ainda a participação dos Estados Unidos, em que a administração Clinton evitou comprometer-se com as necessidades dos países em desenvolvimento - como medidas têxteis e medidas antidumping -, com o intuito de evitar que a negociação em tais temas tivesse um reflexo negativo nas próximas eleições.

Por fim, Barral (2002, p. 20) menciona o fato de que nenhuma rodada, no âmbito do antigo GATT, contara com tantos participantes, como os que agora havia na OMC:

\begin{abstract}
"O que nasceu como um reduzido grupo de 23 países, em 1947, aparecia agora como um enorme encontro entre representantes de 135 Estados, sendo 80 países em desenvolvimento e várias economias em transição, com interesses diversos, em temas variados e pouco dispostos a aceitar não estarem presentes nos green rooms.”
\end{abstract}

Sobre o green room, cabe dizer que se trata de técnica em que os pontos controversos são negociados por número menor de Estados interessados em determinado tema. Na época da negociação de Seattle, países em desenvolvimento da África, do Caribe e da América Latina declararam que rejeitariam publicamente o resultado de tais sessões (BARRAL, 2002, p. 20).

Após o impasse em Seattle, realizou-se, em 2001, Conferência Ministerial em Doha, no Catar. Nela, conseguiu-se estabelecer uma agenda de negociações, a partir de um texto ( $\mathrm{draft}$ ) elaborado pelo Secretariado da OMC. A nova rodada foi lançada com grande expectativa - segundo Amrita Narlikar (2004), o grande indicador de 
que há agora a preocupação com questões do desenvolvimento é o próprio nome com o qual a rodada foi lançada: Doha Development Agenda ${ }^{12}$.

Os países em desenvolvimento conseguiram algumas declarações, como, por exemplo, o compromisso de que as negociações, na Rodada Doha, levariam em conta o princípio de tratamento especial e diferenciado para países em desenvolvimento e países menos desenvolvidos, incorporados na Parte IV, do GATT-1994, na decisão de 28 de Novembro de 1979 sobre Tratamento Mais Favorável e Diferenciado, Reciprocidade e Plena Participação de Países em Desenvolvimento, na decisão da Rodada Uruguai sobre medidas em favor de países menos desenvolvidos e em outras disposições relevantes da OMC (Ministério do Desenvolvimento, Indústria e Comércio Exterior, 2009).

Na prática, entretanto, a Rodada Doha vem demonstrando suas incongruências, pois não se tem conseguido resolver o impasse entre países desenvolvidos e em desenvolvimento. Os primeiros desejam liberalizar o acesso ao mercado dos segundos, com a introdução de produtos industrializados. Os países em desenvolvimento, porém, querem a efetiva liberalização da entrada de produtos primários, nos mercados dos países desenvolvidos. Clamam, também, pela redução dos subsídios agrícolas, os quais são extensivamente praticados pelas potências econômicas, mormente EUA e União Europeia.

Tal impasse é o grande responsável pela delonga na conclusão da rodada. Doha deveria ter alcançado um denominador comum em 2005. Posteriormente, embora fosse um prazo não-oficial, deveria ter sido concluída em 2006. Também não o foi e, em recente Conferência Ministerial, em Genebra, em 2008, apesar de todos os esforços envidados por Pascal Lamy, Diretor-Geral da OMC, não foi possível a conclusão de um acordo. O grande problema foi o fato de a Índia, apoiada pela Argentina, não ter aceito os critérios, desejados pelos EUA, que autorizariam um país pobre a elevar suas tarifas, a fim de defender seus produtores agrícolas.

\footnotetext{
${ }^{12}$ Evitou-se, inicialmente, utilizar o nome 'rodada', talvez em virtude da necessidade de não se dar uma dimensão tão grande à agenda de negociações disposta na declaração ministerial, de Doha, em 2001. O tempo demonstrou, no entanto, que se trata de verdadeira - e ambiciosa - rodada de negociações, de forma a falar-se, sem problemas, em Rodada Doha para o Desenvolvimento.
} 
Ficaram evidentes as discrepâncias no âmbito do G-20. O grupo de geometria variável, criado em Cancún, em 2003, para o fortalecimento das negociações agrícolas, demonstrou não ser uníssono quanto às necessidades de seus membros. $\mathrm{O}$ Brasil, um dos membros e líderes do grupo, queria a conclusão do acordo em 2008.

A questão da agricultura é, de fato, uma das mais complexas e caras aos países em desenvolvimento. Desde 1986, formou-se um fórum com a finalidade de debater-se a liberalização agrícola, no âmbito do comércio internacional: o Grupo de Cairns. O principal objetivo do grupo - composto por Brasil, Austrália, Filipinas, Argentina, Bolívia, Canadá, Chile, Colômbia, Costa Rica, Guatemala, Indonésia, Malásia, Nova Zelândia, Paquistão, Paraguai, Peru, Tailândia, Uruguai e África do Sul. -, inicialmente, era fazer frente à Política Agrícola Comum (PAC) europeia, a qual, nas palavras de Welber Barral (2007, p. 65), “é a mais absurda fonte de despesas, sobretudo subsidiando produtores agrícolas ineficientes”.

O grupo teve sucesso ao colocar a agricultura, um tema esquecido no GATT1947, no âmbito de atuação da OMC e, principalmente, nas negociações da Rodada Doha. Atualmente, embora continue ativo - ocorreu, em junho de 2009, conferência do grupo, em Bali, Indonésia -, a coalizão é liderada pela Austrália, um país rico, de modo que, para países em desenvolvimento, como o Brasil, o G-20 tem sido um fórum mais adequado para suas necessidades - apesar de, como visto, apresentar discrepâncias entre seus membros, como a agricultura familiar da Índia e o forte agronegócio brasileiro.

Espera-se que, em 2010, tal impasse, com relação à liberalização agrícola, possa ser finalmente sanado, e a Rodada Doha atinja pontos convergentes, podendo, então, ser concluída. Pascal Lamy afirmou, em 2009, que há a possibilidade de conclusão da rodada ainda em 2010. A Uniao Europeia, no entanto, já declarou que não fará mais concessões, para se chegar a um acordo. (FOLHA DE SÃO PAULO, 2009)

Enquanto o fechamento da Rodada Doha permanece indefinido, estudaremos, na próxima seção, o sistema de solução de controvérsias da OMC, item indispensável 
para a compreensão do contencioso do algodão, a ser visto no segundo capítulo do presente trabalho.

\subsection{O Sistema de Solução de Controvérsias da OMC}

O sistema de solução de controvérsias do GATT decorreu da prática de seus membros, quanto ao artigo XXIII do acordo. Tal prática, segundo Lafer, foi codificada e objeto de desenvolvimento gradual em vários momentos (1998, p.111). Além disso, o artigo XXIII continua sendo, no âmbito da OMC, o artigo que move o sistema de solução de controvérsias. Conforme o dispositivo, os casos de conflito de interesses entre partes contratantes do GATT poderão ser dirimidos por meio de representação feita pela parte que se sentir prejudicada ${ }^{13}$.

Ademais dele, também similar conteúdo do artigo XXII, do GATT - o qual versa sobre a obrigação de consultar -, encontra-se presente no sistema da OMC, uma vez que o seu Entendimento sobre Solução de Controvérsias (Dispute Settlement Undestanding) dispõe no artigo $3^{\circ}$, parágrafo $7^{\circ}$, que “a solution mutually acceptable

\footnotetext{
${ }^{13}$ Article XXIII: Nullification or Impairment

1. If any contracting party should consider that any benefit accruing to it directly or indirectly under this Agreement is being nullified or impaired or that the attainment of any objective of the Agreement is being impeded as the result of

(a) the failure of another contracting party to carry out its obligations under this Agreement, or

(b) the application by another contracting party of any measure, whether or not it conflicts with the provisions of this Agreement, or

(c) the existence of any other situation, the contracting party may, with a view to the satisfactory adjustment of the matter, make written representations or proposals to the other contracting party or parties which it considers to be concerned. Any contracting party thus approached shall give sympathetic consideration to the representations or proposals made to it.

2. If no satisfactory adjustment is effected between the contracting parties concerned within a reasonable time, or if the difficulty is of the type described in paragraph 1 (c) of this Article, the matter may be referred to the CONTRACTING PARTIES. The CONTRACTING PARTIES shall promptly investigate any matter so referred to them and shall make appropriate recommendations to the contracting parties which they consider to be concerned, or give a ruling on the matter, as appropriate. The CONTRACTING PARTIES may consult with contracting parties, with the Economic and Social Council of the United Nations and with any appropriate inter-governmental organization in cases where they consider such consultation necessary. If the CONTRACTING PARTIES consider that the circumstances are serious enough to justify such action, they may authorize a contracting party or parties to suspend the application to any other contracting party or parties of such concessions or other obligations under this Agreement as they determine to be appropriate in the circumstances. If the application to any contracting party of any concession or other obligation is in fact suspended, that contracting party shall then be free, not later than sixty days after such action is taken, to give written notice to the Executive Secretary1 to the CONTRACTING PARTIES of its intention to withdraw from this Agreement and such withdrawal shall take effect upon the sixtieth day following the day on which such notice is received by him.
} 
to the parties to a dispute and consistent with the covered agreement is clearly to be preferred" ${ }^{\prime 14}$. Assim, tanto no GATT-1947 quanto na OMC, a consulta é sempre o procedimento inicial, a qual, no caso de não ter êxito na elaboração de um acordo entre as partes, será sucedida pela instauração de um painel.

O GATT, segundo Jackson (2000, p.121), continha duas abordagens (approaches) para a solução de controvérsias: a primeira é denominada por ele de diplomacy approach; a segunda, de rule-oriented approach.

Na primeira forma, as controvérsias são dirimidas de modo político, nãonormativo. Por outro lado, na rule-oriented approach, há a segurança jurídica, que permite aos Estados preverem como um tribunal imparcial decidiria certa querela. Consequentemente, tal abordagem levaria os Estados a obedecerem e respeitarem um sistema normativo. Essa capacidade de fornecer segurança e previsão é, para Jackson, essencial aos assuntos internacionais, mormente aos assuntos econômicos.

A evolução das práticas do GATT é mencionada por Lafer como uma passagem, com avanços e recuos, de um sistema que, inicialmente, era power oriented (ou, na linguagem de Jackson, utilizava-se da diplomacy approach), mas que, pelo bem da segurança jurídica, evoluiu para se tornar cada vez mais rule oriented:

\footnotetext{
“A criativa evolução desta prática, num sentido amplo, indica a passagem - com marchas e contra-marchas - de um sistema mais voltado para a conciliação, como era usual nos acordos de produtos primários, por exemplo café (o que Hudek denominou de "jurisprudência diplomática”, ou seja um blend of legal and diplomatic strategies), para um sistema que foi abrindo a possibilidade de um adensamento crescente da “juridicidade" na solução de controvérsias, sem nunca excluir a conciliação negociada dos interesses”. (LAFER, 1998, p. 115)
}

O procedimento para solução de controvérsias inicia-se, como visto, com uma consulta entre as partes. Quando não há acordo nessa fase inicial, a parte reclamante pode solicitar o estabelecimento de um painel (panel). O GATT, no entanto,

\footnotetext{
${ }^{14}$ Tradução da autora: uma solução mutuamente aceitável entre as partes, em uma disputa, e consistente com o presente acordo é claramente preferível.
} 
apresenta como um dos principais problemas para a implantação de um painel o princípio do consensus decision-making (JACKSON, 2000, p. 123), uma vez que é necessário o consenso nas decisões do Conselho do GATT, a fim de que haja a instauração do painel. Dessa forma, quando a parte - que provavelmente perderá uma disputa - faz objeção ao painel, sua adoção é bloqueada ${ }^{15}$, num primeiro momento. Em um segundo momento, não é a instauração do painel que é bloqueada, mas sim o relatório - a decisão - do painel.

Os painéis não têm natureza jurídica de arbitragem, embora sejam compostos por árbitros. Celso Lafer, ao citar Pierre Pescatore, na obra Drafting and Analyzing Decisions on Dispute Settlement, aponta as razões pelas quais a natureza jurídica do painel difere da arbitragem. A primeira delas é o fato de seus membros não serem escolhidos pelas partes; os membros do painel eram escolhidos pelo Secretariado, podendo ser indicados pelo Diretor-Geral. Em segundo lugar, não há um compromisso de arbitragem previamente estipulado entre as partes. Em terceiro lugar, a decisão do painel é um parecer, não uma sentença arbitral ${ }^{16}$. (LAFER, 1998, p. 116-117)

Tanto John Jackson quanto Robert Hudek (1995; 1993) apresentam estatísticas da utilização dos painéis, no sistema GATT-1947, e o que se nota é a sua grande utilização. Jackson contabiliza, até 1989, cerca de 233 casos - dos quais nem todos levaram à instauração de painéis. Hudek afirma que, no período de 1948-1989, houve cerca de 207 reclamações. Desse modo, Jackson conclui, em seu estudo, que a quantidade de casos apreciados no sistema do GATT é muito maior do que os casos apreciados pela Corte Internacional de Justiça (CIJ) - cerca de 100 casos -, no mesmo período.

Havia, no entanto, a necessidade de codificar-se as práticas do GATT, o que levou à criação do Entendimento sobre Solução de Controvérsias (ESC), quando da instituição da OMC (Anexo 2 do Acordo de Marraqueche). Assim, o GATT possuía

\footnotetext{
${ }^{15}$ Segundo Jackson, tal atitude - de bloquear um painel - foi utilizada em muitos casos, no âmbito do GATT, principalmente nos que diziam respeito a subsídios (2000, p. 123).

16 "Os panel reports são, nas palavras de Pescatore, persuasive not precriptive documents". (Lafer, 1998, p. 117)
} 
natureza contratual, enquanto o ESC é parte integrante da constituição da OMC, de modo que os Estados, que dela desejam ser membros, aceitam automaticamente o disposto no Anexo 2.

A principal inovação trazida pelo ESC, em relação à sistemática de solução de controvérsias do GATT-1947, foi a inversão da regra do consenso. Isso significa que, no âmbito da OMC, os painéis só não serão iniciados nem seus relatórios adotados se todos os membros da OMC forem contrários a tais atividades. É denominado, usualmente, de consenso negativo.

Além da inversão da regra do consenso, outra inovação importante trazida pelo ESC foi a criação do Órgão de Apelação (OA, Appellate Body), ou seja, a criação de um órgão de segunda instância, com a capacidade de rever as decisões adotadas pelos painéis. O primeiro caso brasileiro, no Órgão de Apelação, foi o caso United States - Standards for reformulated and conventional gasoline - complaint by Venezuela and Brazil (DS 4). Em 1996, o OSC adotou o relatório do OA, e os Estados Unidos anunciaram a implementação das recomendações do painel em agosto de 1997.

O Órgão de Apelação é composto por sete membros, eleitos para um mandato de quatro anos, sendo permitida uma reeleição. Deve ser ressaltado que a nacionalidade dos membros do OA não é um fator determinante para sua seleção. Dessa forma, também não será um membro excluído de participar do julgamento de determinado caso, na hipótese de pertencer à nacionalidade de uma das partes do contencioso. Assim, difere da apreciação feita pelo painel, na qual o árbitro não poderá possuir a mesma nacionalidade de qualquer das partes - uma vez que, se assim fosse permitido, haveria a presunção de parcialidade do julgador (LAFER, 1998, p. 124).

Embora haja, nas palavras de Lafer (1998), o “adensamento da juridicidade”, advinda com a instituição do ESC, pode-se afirmar que o Órgão de Solução de Controvérsias da OMC é um órgão político-diplomático, porquanto a execução das recomendações do painel e do OA tem sua implementação e aplicação de medidas 
compensatórias - além da suspensão de concessões - dependentes de aspectos eminentemente políticos, como é o caso da conveniência de se aplicar determinada sanção a um Estado.

Segundo Ana Cristina Paulo Pereira (2003, p. 10), o OSC é, sobretudo, um órgão executivo, cujas funções, de acordo com o art. 2 do ESC, são: estabelecer os painéis, quando solicitados por um dos membros da OMC; adotar os relatórios elaborados pelos painéis e/ou pelo Órgão de Apelação; fiscalizar a implementação das decisões e recomendações formuladas; e autorizar a aplicação pela parte vencedora de medidas de retaliação contra a parte recalcitrante. Percebe-se, assim, como decorrência de suas funções, os aspectos políticos que a elas são inerentes.

Outra questão relevante, quanto ao funcionamento do OSC, é a que diz respeito à participação de terceiros. O art. 10 do ESC autoriza que membros da OMC, efetivamente interessados no tema da controvérsia, participem, como terceiros, do painel. Dessa forma, se houver o interesse concreto, poderá o terceiro ser ouvido pelo painel e apresentar informações escritas, não importando se será para auxiliar o reclamante ou o reclamado. Assim, em um mesmo contencioso, o terceiro poderá auxiliar uma ou outra parte, de acordo com seus próprios interesses. Os terceiros, porém, não podem apresentar réplicas, tecer comentários sobre os relatórios dos especialistas, retaliar ou manifestar-se sobre questões não recorridas pelas partes, em sede de apelação (PEREIRA, 2003, p. 12).

Por fim, transcreve-se abaixo uma síntese do procedimento de solução de controvérsias da OMC, o qual foi elaborado pelo Ministério das Relações Exteriores (MRE), e encontra-se disponível, em seu sítio, na internet:

01 - Consultas;

02 - Se as Consultas: a) não são realizadas dentro do $\operatorname{prazo}^{17}$ (30 dias, ou conforme decidido de comum acordo); ou b) não levam a solução

\footnotetext{
${ }^{17}$ Os prazos relacionados à conclusão dos diversos painéis variam muito em função da dinâmica do processo negociador e da natureza da questão envolvida. Somente a título de exemplo, o painel sobre a gasolina venezuelana (Brasil e Venezuela x EUA) durou 2 anos e 7 meses desde seu início até a reversão das medidas adotadas pelos EUA.
} 
mutuamente aceitável, a parte demandante pode solicitar o Estabelecimento de painel;

03 - O painel será estabelecido o mais tardar na reunião do OSC seguinte à reunião em que a solicitação constou pela primeira vez da agenda do Órgão;

04 - O painel será composto, normalmente, por 3 peritos, após consultas às partes em disputa. As partes em litígio, de comum acordo, podem solicitar que o painel seja integrado por 5 peritos. As deliberações dos painéis serão confidenciais;

05 - O painel terá 6, ou, no máximo, 9 meses, em condições habituais, para apresentar seu relatório, a contar da data de seu estabelecimento e da determinação de seus termos de referência;

06 - A parte demandante poderá solicitar a suspensão dos trabalhos do painel, a qual não poderá exceder 12 meses, sob pena de caducar a autoridade para seu estabelecimento;

07 - Etapa Intermediária de Exame: após a apresentação de réplicas e argumentação oral das partes, o painel deve submeter as seções descritivas do projeto de relatório, para comentários das partes. Ultrapassada essa fase, o painel deve elaborar um relatório provisório, ao qual as partes podem oferecer comentários. O relatório provisório, já com as conclusões do painel, será considerado o relatório final, pronto para a circulação entre todos os membros, se não houver comentários;

08 - Adoção do relatório do painel: salvo em casos de apelação, o relatório deverá ser adotado pelo OSC dentro de 60 dias, a contar da data de circulação do documento entre os membros. Os relatórios não serão examinados para efeito de aceitação pelo OSC até 20 dias após a data de distribuição aos Membros;

09 - Apelação: o Órgão de Apelação (OA): composto por 7 integrantes (nomeados para mandato de 4 anos, renovável), 3 dos quais atuarão em cada caso, terá, como regra geral, 60 dias contados a partir da data da notificação formal da decisão de apelar para distribuir seu relatório. $\mathrm{O}$ procedimento não deverá exceder 90 dias. Apenas as partes em controvérsia, excluindo-se terceiros interessados, poderão recorrer do relatório do painel;

10 - Adoção do relatório do Órgão de Apelação: dentro do prazo de 30 dias a contar da distribuição do documento aos membros, a menos que o OSC decida por consenso não adotar o relatório;

11 - Implementação das Recomendações do OSC: em reunião do OSC, dentro de 30 dias após a data de adoção do relatório do Painel ou do Órgão de Apelação, o membro interessado deverá informar ao OSC suas intenções com relação à implementação das decisões e recomendações daquele Órgão. Não sendo possível a implementação imediata, o membro interessado deverá dispor de prazo razoável;

12 - Compensações: se a parte afetada não implementar as decisões e recomendações do OSC dentro do prazo razoável estabelecido, deverá, se solicitada, negociar com a(s) outra(s) parte(s) compensações mutuamente satisfatórias; 
13 - Suspensão da Aplicação de Concessões ("retaliação"): Se dentro dos 20 dias seguintes à data da expiração do prazo razoável determinado não se houver acordado uma compensação satisfatória, quaisquer das partes que hajam recorrido ao procedimento de solução de controvérsias poderá solicitar autorização do OSC para suspender a aplicação de concessões ou de outras obrigações decorrentes dos acordos abrangidos à parte interessada.

14 - Os princípios definidores da suspensão da aplicação de concessões e a determinação de seu valor são objeto de arbitragem;

15 - Após a determinação, pelo comitê de arbitragem, de que maneira e em que valor incidirá a suspensão da aplicação de concessões, a parte interessada deve solicitar autorização ao OSC para poder aplicar aquela suspensão ${ }^{18}$.

Após esse estudo acerca do sistema de solução de controvérsias da OMC, faremos, no próximo capítulo, a estruturação do contencioso do algodão, caso que foi numerado na OMC como DS (Dispute Settlement) 267 e cuja importância reside na vitória histórica contra os subsídios agrícolas e na dimensão da participação de atores não-governamentais, que forneceram análises e materiais, a fim de que o governo brasileiro pudesse levar o caso adiante.

\footnotetext{
${ }^{18}$ MRE. Disponível em: <http://www2.mre.gov.br/cgc/mecanismo\%20solu\%C3\%A7\%C3\%A3o.doc >
} Acesso em Nov/2009. 


\section{O CONTENCIOSO DO ALGODÃO}

O algodão é um produto importante para muitos países em desenvolvimento. De acordo com John Baffes (2004), em relatório do Banco Mundial, durante o período 1998-1999, o algodão figurava entre 30 e 40\% do total de mercadorias exportadas de cinco países produtores da África ocidental: Benin, Burkina Faso, Chad, Mali e Togo. Dessa forma, quando o preço internacional dessa matéria-prima cai, há forte influência nos níveis de riqueza desses países.

O mercado cotonicultor está sujeito a consideráveis intervenções de mercado, principalmente aos subsídios agrícolas dos Estados Unidos, maior produtor e exportador mundial do produto. Segundo Baffes (2004), em 2002, o suporte total ao setor, realizado pelos grandes global players - EUA e União Europeia -, chegou a quase US\$ 6 bilhões, o que significa mais de um quarto do valor de toda a produção mundial de algodão. Assim, o preço do produto atingiu seu menor valor nominal desde 1972 e, possivelmente, seu menor valor real historicamente. Os preços baixos e as políticas domésticas de subsídios causaram várias reações contrárias a tais políticas e o surgimento do que Baffes denominou de cotton problem.

No Brasil, conforme dados obtidos no site do Ministério da Agricultura, a exportação de algodão também sofreu uma queda substancial em 2002. Em 2001, o valor das exportações do produto brasileiro foram de US\$ 154 milhões, mas passaram a ser de US\$ 94 milhões, em 2002, sofrendo, assim, uma redução de 61\% no valor de suas exportações de algodão. A partir de 2003, ano em que o painel do algodão já estava instaurado na $\mathrm{OMC}$, as exportações voltaram a subir, e o último dado do Ministério da Agricultura informa que, em 2006, as exportações do produto foram de US\$ 300 milhões, ou seja, houve um aumento de 319\% em relação a 2002.

Como lembrado por Phoenix Cai (2009), no que tange ao comércio internacional, são dois os meios de os países alcançarem seus objetivos e solucionarem eventuais controvérsias: a negociação ou o litígio. Embora os países em desenvolvimento tenham feito uso de ambos os instrumentos, é possível afirmar que a negociação é uma forma historicamente mais utilizada. Mencionam-se, como 
exemplos, as negociações no âmbito da Conferência das Nações Unidas para o Comércio e o Desenvolvimento (UNCTAD), as no âmbito do GATT-1947 e as rodadas da OMC. Percebe-se, no entanto, que o instrumental político tem deixado a desejar, como se observa pela atual paralisia da Rodada Doha. Desse modo, o meio jurídico tem se tornado cada vez mais importante na solução de impasses comerciais, ainda mais quando, na OMC, há um mecanismo muito mais eficaz para solução de controvérsias do que aquele verificado no GATT-1947.

O contencioso do algodão e a vitória brasileira contra os Estados Unidos servem como incentivo aos países em desenvolvimento para pleitearem, de modo mais amplo, a redução dos subsídios praticados pelas grandes potências em outros produtos, como, por exemplo, os subsídios norte-americanos ao milho (CAI, 2009). Devem, ainda de acordo com CAI (2009), servir de alerta, para que as nações dêem mais atenção aos compromissos políticos, retomando a Rodada Doha, de forma a se chegar a um acordo que contemple, de modo satisfatório, a questão dos subsídios agrícolas. Caso contrário, o comércio internacional poderá estar fadado à esfera bilateral e jurídica.

Antes de analisarmos o contencioso do algodão propriamente, cabe fazer um breve estudo de dois acordos da Rodada Uruguai, que amparam o pleito brasileiro: o Acordo sobre Agricultura (AA) e o Acordo sobre Subsídios e Medidas Compensatórias (ASMC). Além deles, também importa discorrer um pouco sobre a Farm Bill norte-americana.

\subsection{O Acordo sobre Agricultura e o Acordo sobre Subsídios e Medidas Compensatórias}

A Rodada Uruguai, pela primeira vez na história do comércio internacional, colocou restrições aos subsídios agrícolas, e dois acordos complexos normatizam tais restrições: o Acordo sobre Agricultura (AA) e o Acordo sobre Subsídios e Medidas Compensatórias (ASMC). Este regula os subsídios a todos os setores econômicos, não apenas os agrícolas, mas submete-se ao AA pelo artigo 21 deste, o qual diz, 
expressamente, que as disposições dos outros acordos da OMC estão sujeitas às normativas do Acordo sobre Agricultura ${ }^{19}$.

O ASMC, originariamente, distinguiu os subsídios acionáveis daqueles proibidos. Até o ano 2000, havia ainda os subsídios permitidos (caixa verde), constantes no artigo 8 do ASMC. A partir de 2000, subsistem apenas os subsídios acionáveis (caixa amarela) e os proibidos (caixa vermelha). Os primeiros são permitidos desde que não causem efeitos adversos. No caso de os causarem, a parte prejudicada deverá demonstrar os prejuízos sofridos e pleitear uma reparação. Geralmente, os subsídios acionáveis são os domésticos, que não estão diretamente atrelados a uma substituição de produtos importados, uma vez que os subsídios à exportação ou aqueles à substituição de importações são proibidos de imediato, não havendo a necessidade de uma ação da parte prejudicada. Dessa forma, os subsídios proibidos ou "red light” são os que mais distorcem o comércio internacional e, por isso, são per se ilegais (CAI, 2009, p. 871).

O exemplo utilizado por CAI (2009, p. 870 e 872), para diferenciar os subsídios acionáveis dos proibidos, é o seguinte: se os EUA oferecem US\$ 0,50 por alqueire de milho que é destinado à exportação, bem como US\$ 0,50 por alqueire de milho norte-americano utilizado na produção de etanol, têm-se ilustrações de subsídios proibidos. O primeiro exemplo é de subsídio à exportação e o segundo, de subsídio doméstico, com o intuito de substituir importações. Por outro lado, os subsídios acionáveis ocorreriam quando os EUA oferecessem US\$ 0,50 por alqueire de milho produzido. Nesse caso, por não estar vinculado à exportação nem à substituição de importações, os países que se sentissem prejudicados com tal subsídio deveriam, necessariamente, demonstrar o dano a suas economias.

O Acordo sobre Agricultura, por sua vez, não utiliza a "Caixa Vermelha”, como o faz o Acordo sobre Subsídios e Medidas Compensatórias. No AA, os

\footnotetext{
${ }^{19}$ O Artigo 21 do Acordo sobre Agricultura assim dispõe: "1. The provisions of GATT 1994 and of other Multilateral Trade Agreements in Annex 1A to the WTO Agreement shall apply subject to the provisions of this Agreement".
} 
subsídios relacionados à exportação não são necessariamente ilegais. Estão, na verdade, subordinados a um limite sobre o valor e sobre a quantidade.

Assim, os países desenvolvidos comprometeram-se a diminuir seus subsídios à exportação em 36\%, quanto ao valor, e, em $21 \%$, quanto à quantidade, no prazo de seis anos. Já as nações em desenvolvimento devem cortar, no prazo de dez anos, 24\% dos subsídios à exportação, quanto ao valor, e 14\%, quanto à quantidade. Por fim, os países de menor desenvolvimento relativo, os chamados "LDCs" (least developed countries), não fizeram nenhum compromisso de reduções.

No que concerne aos subsídios domésticos (ou medidas de apoio interno), o Acordo sobre Agricultura apresenta três “Caixas” para eles: "amarela”, “azul” e "verde”. A primeira é considerada a que contém os subsídios mais distorcivos ao comércio internacional. Dentre eles, encontram-se os subsídios vinculados à quantidade de produção e aqueles ligados ao preço corrente de mercado (que pagam a diferença entre o preço do produtor doméstico - mais caro - e o preço de mercado - mais barato).

A Caixa Azul contém subsídios menos distorcivos ao mercado do que os da Caixa Amarela, pois há nela limites à produção, como, por exemplo, cotas ou reservas de terras por parte dos produtores. Na atual Rodada Doha, a Caixa Azul é um ponto importante nos debates. Isso porque seria fácil transitar da Caixa Amarela para a Azul, mascarando, assim, o potencial de lesão de certo subsídio. Dessa forma, alguns países desejam limites à utilização da Caixa Azul, enquanto outros defendem que essa categoria seja totalmente eliminada e os subsídios abrangidos por ela passem a compor a Caixa Amarela (CAI, 2009, p. 876 e 877).

Os subsídios da Caixa Verde são considerados medidas de efeito mínimo ou nulo no comércio internacional. Dentre eles estão o apoio à pesquisa, à luta contra pragas e doenças, a ajuda alimentar para setores carentes da população, o apoio à divulgação e à infraestrutura etc. (SCHIMANSKI, 2006, p. 21) Logo, são medidas de apoio que não podem estar relacionadas a preços e, apesar de não serem efetivamente 
objeto de contendas na Rodada Doha, alguns tipos de subsídios da Caixa Verde foram questionados ${ }^{20}$.

A Cláusula de Paz, contida no artigo 13 do Acordo sobre Agricultura, concedeu uma vacância de nove anos, a contar de 1995 (artigo 1, f), período no qual os países não poderiam ser acionados perante o sistema de solução de controvérsias da OMC. O propósito era de que os países-membros adequassem a prática de subsídios aos termos do acordo. Tal prazo, no entanto, expirou em 2004, o que possibilitou ao Brasil demandar os EUA na OMC. Apesar disso, é importante notar que, no caso do algodão (DS 267), como veremos adiante, contestou-se subsídios anteriores ao término da vacância da Cláusula de Paz.

\subsection{A Farm Bill norte-americana}

De acordo com Silvana Schimanski (2006, p. 33), o apoio à agricultura norteamericana iniciou-se, na década de 1930, com o New Deal, do presidente Roosevelt. O programa intervencionista fez-se necessário em razão da crise econômica do período. Daí em diante, passou a haver dois grupos distintos nos EUA, quanto às questões agrícolas: aquele a favor das intervenções do Estado (“family farm”) e aquele a favor de políticas mais liberais - geralmente, representantes urbanos, que desejam a diminuição dos gastos governamentais com o setor agrícola.

As farm bill ${ }^{21}$ são negociadas para valer por cinco anos e representam, assim, o momento econômico vivido pelos Estados Unidos em certo período. A Farm Bill de 1996 significou uma inovação, no sentido de ser mais liberal. Ela incorporou as normativas negociadas no âmbito da OMC e previu redução do montante de subsídios agrícolas. Apesar disso, com a crise asiática de 1997 e a conseqüente

\footnotetext{
20 "Some countries have argued in Doha that some Green Box subsidies may not meet the minimally trade-distorting test, either because of the large amounts paid or because of the nature of the subsidies themselves. Examples of subsidies that may be reclassified or limited as a result of the Doha Round include direct payments to farmers, decoupled income support, and government support for income insurance and income guarantee or safety-net programs". (CAI, 2009, p. 878)

21 "The farm bill is a large omnibus reauthorization with a budget of approximately \$ 16.5 billion and covers not only farm subsidies, but also programs for environmental conservation, nutrition programs, and loans for farms ownership as well as funding for research related to these programs". (CAI, 2009, p. 880)
} 
alteração do momento econômico mundial, o lobby protecionista norte-americano pressionou por aumento nas intervenções governamentais, com o fim de proteger os produtores domésticos.

Dessa forma, a Farm Bill de 2002 pode ser considerada um retrocesso na política agrícola dos EUA, uma vez que reinstituiu os programas de pagamentos diretos aos produtores do país e formalizou pagamentos contra-cíclicos que, na verdade, funcionam como uma garantia de preço ao produtor local, a fim de manter a competitividade no mercado internacional. O problema é que tais medidas são extremamente distorcivas e foi, no contexto dessa farm bill, que o Brasil iniciou suas consultas à OMC quanto ao algodão.

Um dos tipos de subsídios da Farm Bill de 2002 é conhecido como Step 2. Oficialmente, o programa chama-se Upland Cotton User Marketing Certificate Program. De acordo com Schimanski (2006, p. 39 e 40), trata-se de pagamentos a exportadores e consumidores - no caso, a indústria têxtil dos EUA -, com o intuito de cobrir a diferença entre o preço doméstico e o internacional. Para os Estados Unidos, o programa não contrariava as normativas da OMC, mas, no contencioso do algodão, foi demonstrado que tais subsídios não estavam em conformidade com os acordos da organização.

A Farm Bill de 2007 foi promulgada com muito atraso, em junho de 2008, haja vista as negociações entre governo, congresso e grupos de pressão. Segundo Phoenix Cai (2009, p. 882), o ex-presidente George W. Bush chegou a vetar essa lei, porque ela não atendia ao regime fiscal de sua administração. A norma, no entanto, não é compatível com os regramentos da OMC, pois ainda permite os distorcivos pagamentos contra-cíclicos.

Houve, no entanto, a tentativa de desvincular tais pagamentos quanto à garantia de preço - o que era flagrantemente incompatível com o Acordo sobre Agricultura -, para deixá-los relacionados à renda do produtor. É claro, contudo, que, mesmo assim, os pagamentos ficam indiretamente vinculados a preços e têm, ainda, efeitos bastante distorcivos ao comércio internacional. Na atual Rodada Doha, os 
países em desenvolvimento vêm combatendo a farm bill e alegam que, da forma como estão, os subsídios norte-americanos compõem a Caixa Amarela do AA.

Cabe observar, por fim, que a Farm Bill de 2007 foi utilizada pelos EUA como justificativa para o atraso em cumprir as determinações da OMC no contencioso do algodão, que deu ganho de causa ao Brasil. Alegou-se que era necessário aguardar o debate da norma no Congresso, pois ela iria adequar-se ao parecer da OMC. Como se sabe, não foi o que ocorreu e, dessa forma, conforme estudaremos adiante, o Brasil pediu autorização para utilizar contramedidas em face dos Estados Unidos.

\subsection{O Caso do Algodão na OMC (DS 267)}

Em outubro de 2002, o Brasil iniciou o procedimento de consulta aos Estados Unidos, na OMC. Questionou subsídios à exportação e de apoio doméstico ao setor cotonicultor, no período de 1999 a $2002^{22}$, além da Farm Bill de $2002^{23}$.

\footnotetext{
22 “- Subsidies and domestic support provided under the Agricultural Risk Protection Act of 2000 and any other measures that provide subsidies relating to crop, disaster or other types of insurance to the US upland cotton industry;

- Subsidies and domestic support provided under the Federal Agricultural Improvement and Reform Act (FAIR Act) of 1996, and programs under the FAIR Act or amendments thereto relating to marketing loans, loan deficiency payments, commodity certificates, production flexibility contract payments, conservation payments, Step 2 certificate program payments, export credit guarantees, and any other FAIR Act provisions providing direct or indirect support to the US upland cotton industry;

- Export subsidies, exporter assistance, export credit guarantees, export and market access enhancement to facilitate the export of US upland cotton provided under the Agricultural Trade Act of 1978, as amended, and other measures such as the GSM-102, GSM-103, and SCGP programs, and the Step 1 and Step 2 certificate programs, among others;

- Subsidies provided to the US upland cotton industry under the Agricultural Act of 1949 as amended;

- Export subsidies provided to exporters of US upland cotton under the FSC Repeal and Extraterritorial Income Exclusion Act of 2000 ("ETI Act");

- Subsidies provided under the Agriculture, Rural Development, Food and Drug Administration and Related Agencies Appropriation Act of 2002 (November 2001), the Crop Year 2001 Agricultural Economic Assistance Act (August 2001), the Agriculture, Rural Development, Food and Drug Administration, and Related Agencies Appropriations Act of 2001 (October 2000), the Agriculture, Rural Development, Food and Drug Administration, and Related Agencies Appropriations Act of 2000 (October 1999), and the Agriculture, Rural Development, Food and Drug Administration, and Related Agencies Appropriations Act of 1999 (October 1998);
}

- All subsidies or support measures benefiting upland cotton that have trade-distorting effects or effects on production by the US upland cotton industry, or that have an effect of providing price support for upland cotton, or that are otherwise not exempt from the reduction commitments of the United States, as described in Annex 2 of the Agreement on Agriculture, because they do not meet the 
Cai (2009, p. 886 a 894) divide os argumentos do Brasil em cinco categorias: i. a cláusula de paz não impede a ação; ii. os pagamentos diretos não são subsídios contidos na Caixa Verde; iii. o programa Step 2 é ilegal; iv. os programas de garantia à exportação não estão em conformidade com as normas da OMC; v. os subsídios ao algodão causaram sérios danos ao Brasil. Analisaremos abaixo o desenvolvimento de cada um desses argumentos utilizados pelo Brasil no caso.

\subsubsection{A Cláusula de Paz não impede a ação}

Como visto anteriormente, a Cláusula de Paz do Acordo sobre Agricultura fixou um prazo de nove anos em que os países não poderiam ser demandados na OMC. O Brasil, entretanto, afirmou que a cláusula não impedia todo e qualquer tipo de litígio, mas apenas para certos tipos de subsídios (montantes pré-negociados na Rodada Uruguai), nos quais não se encontravam os praticados pelos EUA quanto ao algodão.

Assim, o Brasil demonstrou que os Estados Unidos não faziam jus à proteção constante na cláusula, uma vez que excederam os compromissos de redução de subsídios fixados no Acordo sobre Agricultura. O País obteve êxito ao comprovar que os subsídios norte-americanos, em 2001, eram maiores que os de 1992. Vale lembrar que a base do Acordo sobre Agricultura, para os compromissos de redução, eram os subsídios praticados em 1992.

policy-specific criteria and conditions set out in paragraphs 2-13 of Annex II of the Agreement on Agriculture (i.e. they are not so-called green box subsidies);

- Export subsidies, domestic support, and other subsidies provided under regulations, administrative procedures, administrative practices and any other present measures, amendments thereto, or future measures implementing any of the measures listed above, that provide for or facilitate the payment of domestic support, export subsidies, and other subsidies for the production, use and/or export of US upland cotton and upland cotton product”. (OMC, 267-1)

23 "Subsidies and domestic support provided under the Farm Security and Rural Investment Act of 2002 (FSRIA), including the regulations, administrative procedures and other measures implementing FSRIA related to marketing loans, loan deficiency payments (LDPs), commodity certificates, direct payments, counter-cyclical payments, conservation payments (to the extent they exceed the costs of complying with such programs), Step 2 certificate program payments, export credit guarantees, and any other provisions of FSRIA that provide direct or indirect support to the US upland cotton industry"(OMC, 267-1) 
Tanto o painel quanto o Órgão de Apelação da OMC confirmaram a alegação feita pelo Brasil, no que concerne à Cláusula de Paz.

\subsubsection{Os pagamentos diretos não são subsídios contidos na Caixa Verde}

Para os Estados Unidos, os pagamentos diretos faziam parte da chamada Caixa Verde. Logo, seriam considerados subsídios legais. O Brasil, entretanto, afirmou que os pagamentos diretos contidos na Farm Bill de 2002 deveriam fazer parte da Caixa Amarela, ou seja, ser acionáveis e estar sujeitos a reduções.

O Anexo 2 do Acordo sobre Agricultura traça os requisitos para que um subsídio conste da Caixa Verde. Dentre eles, o principal, segundo Cai (2009, p. 888), é que os pagamentos estejam desvinculados da produção (decoupled). Dessa forma, o Brasil alegou que os pagamentos diretos feitos pelos EUA não estavam desvinculados da produção de algodão, uma vez que eles eram reduzidos quando a área era utilizada para o plantio de outros produtos, como frutas, verduras e arroz selvagem. ${ }^{24}$

Tanto o painel quanto o Órgão de Apelação da OMC confirmaram o pleito brasileiro, em relação ao fato de os pagamentos feitos pelos EUA vincularem a produção.

\subsubsection{O programa Step 2 é ilegal}

O programa norte-americano conhecido como Step 2 foi o único a tratar exclusivamente de subsídios ao algodão. Consistia em incentivos à compra e à exportação do produto, de modo a não permitir a queda do preço doméstico relativamente ao preço internacional. O Brasil criticou o programa ao afirmar que os subsídios, por influenciarem nas exportações, deveriam ser considerados per se ilegais, nos termos do Acordo sobre Subsídios e Medidas Compensatórias.

\footnotetext{
${ }^{24}$ DS 267. Ver relatório do painel no site da OMC.
} 
O Brasil conseguiu demonstrar que os produtores de algodão norteamericanos só obtinham os benefícios do programa caso provassem que exportavam o produto, configurando, assim, claramente natureza de subsídios à exportação, proibidos pelo ASMC. Os Estados Unidos tentaram em vão caracterizá-los como parte da Caixa Amarela do Acordo sobre Agricultura, com o intuito de retirá-los da aplicação do ASMC.

Tanto o painel quanto o Órgão de Apelação entenderam que o Brasil tinha razão e aceitaram o argumento de que o programa Step 2 era ilegal, nos termos do ASMC.

2.3.4 Os programas de garantia à exportação não estão em conformidade com as normas da OMC

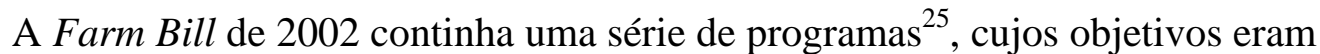
financiar a exportação de produtos agrícolas norte-americanos, dentre eles o milho e o algodão. Foram analisados dois tipos de programas: i. os denominados GSM 102 e 103 (programas de garantia de crédito à exportação); e ii. o SCGP (programa de garantia de crédito ao fornecedor). A diferença entre ambos é no tempo de duração do crédito, mas os dois são, fundamentalmente, créditos à exportação, que atuam de modo a facilitar a importação do produto pelos países compradores, uma vez que têm taxas de juros baixas no financiamento da compra do produto agrícola.

Desse modo, tais créditos foram considerados subsídios à exportação, tanto pelo painel quanto pelo Órgão de Apelação da OMC, e incluídos na proibição constante do ASMC.

\subsubsection{Os subsídios ao algodão causaram sérios danos ao Brasil}

De acordo com Cai (2009, p. 894), a decisão do painel, quanto aos prejuízos sofridos pelo Brasil, com os subsídios ao algodão, não foi clara e, por isso, sofreu algumas críticas e deu margem a muitas discussões sobre os valores do dano efetivo.

${ }^{25}$ Ver notas de rodapé $n^{\circ} 24$ e $n^{\circ} 25$. 
O painel confirmou que o Brasil sofreu efeitos adversos, em razão dos subsídios norte-americanos e que, de fato, houve distorção no mercado internacional, nos anos de 1999-2002. Apesar disso, não deixou explícitos os critérios de cálculo nem os montantes do prejuízo. Para o Órgão de Apelação, o painel procedeu da maneira correta, uma vez que não houve requerimento para que fosse quantificado precisamente o benefício concedido pelos subsídios norte-americanos ${ }^{26}$.

\subsubsection{Implementação dos relatórios do DS 267 e desdobramentos do caso}

Tanto o painel quanto o Órgão de Apelação da OMC solicitaram aos Estados Unidos que retirassem as medidas de apoio ao algodão acima relatadas, consideradas ilegais. No caso de subsídios acionáveis, o país pode retirá-los ou, se preferir, pagar uma compensação - geralmente negociada entre as partes - pelos prejuízos causados. Em último caso, conforme vimos ao estudar o sistema de solução de controvérsias, se os EUA não tomam nenhuma providência e continuam com a prática distorciva, o Brasil pode solicitar uma autorização para aplicar medidas retaliatórias. Como veremos, foi isso o que ocorreu no caso do algodão.

Os Estados Unidos, a despeito do não-cumprimento de todas as decisões do Órgão de Solução de Controvérsias (OSC), retirou, em sua totalidade, os subsídios ao algodão concedidos pelo programa Step 2, em agosto de 2006. Quanto aos pagamentos diretos, aos contra-cíclicos e às garantias à exportação, o painel solicitou que os EUA tomassem as medidas necessárias para retirá-los ou remover os efeitos adversos que tais apoios causavam.

Em 2005, o Departamento de Agricultura norte-americano instituiu uma estrutura de taxas baseadas no cálculo de risco - espécie de seguro contra a diminuição das exportações - e eliminou um dos programas de garantia à exportação. Segundo Cai (2009, p. 896), entretanto, tais taxas não funcionam como um seguro, mas muito mais como verdadeiros subsídios, de forma que a OMC poderá ainda se

\footnotetext{
${ }^{26}$ Ver relatório do OA no site da OMC: "[...] it was not required to quantify precisely the benefit conferred on upland cotton by the price-contingent subsidies".
} 
manifestar acerca delas e acerca de a Farm Bill de 2007 estar ou não em conformidade com as decisões do contencioso do algodão (DS 267).

O grande problema, na implementação das decisões do OSC, tem sido os pagamentos contra-cíclicos. A Farm Bill de 2007 não desvinculou tais pagamentos da produção e do preço. Os Estados Unidos seguem pressionando, em Doha, para a criação de uma nova definição da Caixa Azul, em que tais pagamentos estariam protegidos e não seriam mais ilegais. O G-20, entretanto, resiste ao apelo norteamericano, e o impasse em Doha continua, como observado no encontro de julho de 2008.

Uma vez que as decisões dos organismos internacionais - mesmo as da OMC - dependem, para ser eficazes, de serem aceitas no plano doméstico, o Brasil, pacientemente, aguardou as definições norte-americanas quanto à Farm Bill de 2007. Como a nova legislação agrícola dos EUA não estava em conformidade com as decisões adotadas no caso do algodão, o Brasil, em junho de 2008, solicitou a retomada (resumption) do procedimento de arbitragem ${ }^{27} 28$ e autorização para aplicar contramedidas aos Estados Unidos. Em 31 de agosto de 2009, houve a decisão dos árbitros, que autorizou a aplicação de contramedidas, mas o mecanismo de cálculo foi diferente do desejado pelo Brasil, e o montante final foi bem aquém do pedido inicial de US\$ 4 bilhões.

Interessante notar que dois procedimentos de arbitragem correram em paralelo: um com relação aos subsídios proibidos e outro quanto aos subsídios acionáveis. Os Estados Unidos desejavam decisões separadas para cada um, porém o Brasil solicitou que a decisão condensasse o montante devido quanto a ambos os subsídios. Os árbitros, no entanto, preferiram elaborar decisões separadas para cada tipo de subsídio.

\footnotetext{
${ }^{27} \mathrm{~N}$. A. O termo arbitragem refere-se aqui aos procedimentos de cálculo, para se chegar à quantia devida pela parte. É o termo utilizado pela OMC: arbitration.

28 "On 20 June 2008, the DSB adopted the reports of the Article 21.5 compliance panel and the Appellate Body (WT/DS267/37), which found that measures taken by the United States to comply with the recommendations and rulings of the DSB in this dispute were inconsistent with the covered agreements. Upon instructions from my authorities, and in accordance with paragraph 10 of the "Agreed Procedures", I hereby request the resumption of the above-mentioned arbitration proceedings." (OMC, DS 267)
} 
O Brasil solicitou US\$ 350 milhões em contramedidas, pelo período em que o programa Step 2 foi considerado ilegal e a sua efetiva retirada pelos Estados Unidos (2005-2006). Os árbitros, contudo, não deram razão ao Brasil, porquanto, de acordo com um caso precedente (EC - Bananas III), o propósito das contramedidas, contidas no artigo 4.10 do ASMC, é justamente levar a parte a cumprir as decisões do painel. Logo, os EUA, por retirarem o programa Step 2, não deviam ser punidos com contramedidas referentes aos subsídios de um programa já retirado ${ }^{29}$.

O Brasil também solicitou US\$ 3 bilhões em contramedidas, haja vista os subsídios constantes dos programas norte-americanos GSM 102, 103 e SCGP. O cálculo brasileiro foi realizado de acordo com o montante de subsídios concedidos, porém os árbitros consideraram que deveria ser observado o real valor da distorção do mercado, uma vez que seria mais apropriado para evitar certa desproporcionalidade quando da aplicação das contramedidas.

Desse modo, os árbitros aplicaram a "fatia” de mercado das exportações brasileiras, de produtos constantes do GSM 102, para calcular a distorção causada no mercado brasileiro pelos subsídios do programa norte-americano. De acordo com a tabela abaixo, o total da parcela brasileira equivalia, em 2006, a 11,7\%:

Brazil's Share of World Trade in GSM 102 Products, 2006.

\begin{tabular}{|l|r|r|c|}
\hline \multicolumn{1}{|c|}{ GSM 102 Product } & \multicolumn{1}{c|}{ Brazil Exports } & \multicolumn{1}{c|}{ World Exports } & Brazil Share \\
\hline Cotton & $341,275,226$ & $9,280,297,827$ & $3.7 \%$ \\
\hline Oilseeds & $5,689,902,478$ & $21,519,800,311$ & $26.4 \%$ \\
\hline Protein meals & $2,440,792,339$ & $16,945,389,808$ & $14.4 \%$ \\
\hline Feed Grains & $481,894,034$ & $12,987,102,389$ & $3.7 \%$ \\
\hline Corn Products (Starch) & $8,781,310$ & $406,633,699$ & $2.2 \%$ \\
\hline Hides/ Skins & $2,693,441$ & $4,257,484,051$ & $0.1 \%$ \\
\hline Tallow & $19,710,974$ & $3,606,485,104$ & $0.5 \%$ \\
\hline Rice & $59,872,132$ & $10,158,656,158$ & $0.6 \%$ \\
\hline
\end{tabular}

${ }^{29}$ Ver site da OMC (DS 267, ARB1). 


\begin{tabular}{|l|r|r|c|}
\hline \multicolumn{1}{|c|}{ GSM 102 Product } & \multicolumn{1}{c|}{ Brazil Exports } & \multicolumn{1}{c|}{ World Exports } & Brazil Share \\
\hline Poultry Meat & $3,038,988,127$ & $12,121,810,169$ & $25.1 \%$ \\
\hline Pig Meat & $1,010,288,388$ & $20,653,942,499$ & $4.9 \%$ \\
\hline TOTAL & $13,094,198,449$ & $111,937,602,015$ & $11.7 \%$ \\
\hline
\end{tabular}

Fonte: Decisão dos árbitros, de 31 de agosto de 2009 (OMC, DS 267, ARB1, p. 57).

Por essa razão e por outras diferenciações nos métodos de cálculos, os árbitros concluíram que o Brasil tinha o direito de aplicar contramedidas no valor de US\$ 830 milhões. Deste montante, US\$ 560 milhões deveriam ser aplicados no comércio de bens, e US\$ 270 milhões foram autorizados a ser aplicados em outros acordos, como o GATS e o TRIP. A autorização à retaliação-cruzada, isto é, em outros acordos da OMC, é um precedente importante.

Com o objetivo de por em prática a autorização concedida pela OMC, em 10 de fevereiro de 2010, o governo brasileiro editou a Medida Provisória (MP) $n^{0} 482$, que estabelece os procedimentos que poderão ser adotados para retaliar os americanos na área de propriedade intelectual. As sanções poderão ir desde um bloqueio temporário de remessa de royalties até a quebra de patentes. Ressalte-se que a Câmara de Comércio Exterior (CAMEX) é responsável pela análise preliminar da aplicação das medidas constantes na MP (art. $9^{\circ}$ ). Essa cautela é necessária, uma vez que a retaliação-cruzada jamais foi utilizada por outro membro da OMC.

O Brasil, dessa forma, deve ter cuidado na implementação da norma e o governo parece saber disso. A diplomacia brasileira espera que ainda surja uma solução negociada com os Estados Unidos. O Ministro das Relações Exteriores, Celso Amorim, deixou isso claro quando do lançamento da MP:

"O Brasil tem um caso na OMC que dura sete anos contra os subsídios ao algodão nos EUA. Quando ganhamos na primeira instância, jornais americanos disseram: 'sabíamos que subsídios eram imorais, hoje sabemos que são ilegais'. O que o Brasil está fazendo é dando todos os passos internos para poder aplicar essas retaliações. Mantemos a esperança de que, daqui até o momento da apliçção das retaliações, surja uma proposta que nos convença que há outra saída." (Grifouse) (VALOR ECONÔMICO, 2010) 
Os Estados Unidos, por enquanto ${ }^{30}$, ainda não apresentaram uma proposta de acordo ao Brasil. Pode-se afirmar que, enquanto não há um acordo com os EUA nem as medidas retaliatórias são efetivamente implementadas, parece certo que o contencioso do algodão contribuiu para aumentar o prestígio do país no exterior:

"Brazil has long been a champion of the Doha round WTO trade talks, which stalled after the United States, the European Union and others were unable to walk away from agricultural protectionism - the last stumbling block to the WTO's liberalization process. By pitting the key U.S. interest in IPR against its subsidization policies, Brazil may have found the key to pressuring the United States on protectionism. This single dispute will not likely crack the resolve of the U.S. Congress. However, as an up-and-coming economic power, Brazil stands a good chance of setting a precedent for any of the WTO's 152 other member countries - including economic heavyweights such as China and India - to use WTO-sanctioned retaliation against intellectual property to leverage progress on agricultural trade liberalization”. (Grifou-se) (STRATFOR, 2010)

Um dos pontos mais importantes na análise do contencioso do algodão é a participação de outros atores - como a Associação dos Produtores de Algodão (ABRAPA) e os estudos feitos pela OXFAM Internacional -, sem os quais o caso pudesse não ser levado adiante. Assim, no próximo capítulo, estudaremos a atuação desses outros agentes.

${ }^{30}$ Ressalte-se que o presente trabalho é finalizado em março de 2010. 


\section{PROCESSO DECISÓRIO EM POLÍTICA EXTERNA: OS ATORES DO CASO DO ALGODÃO}

Para Cristopher Hill (2003, p. 53), o processo decisório deve ser o ponto de partida para se compreender os dilemas de atuar no sistema internacional. Uma agência, seja ela governamental ou não, consiste em indivíduos que tomam decisões e as implementam, em nome de entidades que possuem variados níveis de coerência, organização e poder.

Hill (2003, p. 53) ilustra isso com o fato de afirmações de que “o Japão deseja um assento permanente no Conselho de Segurança da Organização das Nações Unidas” ou que “o Iraque invadiu o Kuwait” terem, em si mesmas, um sentido. Apesar disso, ou seja, apesar de o Estado ser, nos exemplos acima, o agente de uma ação no plano internacional, o que está por trás de tais tomadas de decisões? O Iraque não decidiu invadir o Kuwait de uma hora para outra e, além disso, quem assume a responsabilidade pelas decisões do ator estatal?

A relevância dessa análise para o presente trabalho é que, da mesma forma, quando se fala que “o Brasil questionou os subsídios norte-americanos na OMC”, há todo um processo decisório por trás disso. Quem são os indivíduos responsáveis por tal decisão? Quais são as instituições que dela participaram? Por que houve tal necessidade? Quais são os custos envolvidos? Todas essas são questões importantes para identificar a dimensão da decisão tomada. Afinal, mais do que um assunto técnico, decidir levar um caso à OMC é uma decisão de cunho político.

Judith Goldstein e Robert Keohane (1993, p. 11-13) discorrem acerca da influência das idéias em política externa. Afirmam que elas possuem três aspectos relevantes: i. uma vez que os indivíduos precisam identificar seus objetivos e entender o porquê de determinado plano de ação ser melhor estratégia do que outro, as idéias funcionam como um mapa, isto é, elas mostram o caminho (ideas serve as road map); ii. as idéias ajudam a agregar indivíduos e instituições, para, em cooperação, atingirem determinada meta - ressalte-se que tal objetivo jamais poderia ser pior do que a manutenção do status quo (ideas contribute to outcomes in the 
absence of a unique equilibrium); iii. por fim, as idéias, uma vez institucionalizadas e normatizadas, servem para operacionalizar determinada política (ideas embedded in institutions specify policy in the absence of innovation).

O caso do algodão foi uma iniciativa da Associação Brasileira dos Produtores de Algodão (ABRAPA) e do Ministério da Agricultura. Posteriormente, houve participação do Ministério das Relações Exteriores (MRE) e outros atores, como a OXFAM, terceiros países e até de um consultor cujos honorários foram pagos pela indústria têxtil. A participação desses atores está relatada na obra A saga do algodão, realizada pela ABRAPA, em 2004. Conforme será demonstrado, atores individuais, dentro dessas instituições, foram determinantes para o sucesso do caso.

\subsection{O agronegócio brasileiro}

O agribusiness, de modo geral, é conceituado como toda atividade relacionada à comercialização de produtos agropecuários. Quanto ao algodão, de acordo com Wagner Iglécias (2007, p. 76), ele faz parte de uma cadeia produtiva em que há ainda maior complexidade, porque é competitivo, há investimento em pesquisa e tecnologia e está inserido no mercado comercial global.

O produtor rural necessita do apoio do Estado em todas as suas três esferas estadual, municipal e federal -, para poder desenvolver sua atividade. Ele é afetado pelas políticas macroeconômicas governamentais, mormente pela taxa de juros e pela taxa de câmbio, uma vez que um câmbio valorizado é prejudicial a suas exportações. Também precisa do investimento público em logística e em infraestrutura, os quais promovem melhores condições de armazenagem, transporte e distribuição de produtos agropecuários (IGLÉCIAS, 2007, p. 77).

A Constituição de 1891 foi o marco legal da criação e do funcionamento das primeiras organizações rurais, como a Sociedade Nacional da Agricultura (SNA), fundada no Rio de Janeiro em 1897, e a Sociedade Rural Brasileira (SRB), fundada em São Paulo em 1919. A SNA foi a primeira entidade de representação autônoma dos produtores rurais brasileiros e atuou como importante interlocutor do governo 
durante a República Velha, tendo tido papel fundamental na criação do Ministério da Agricultura, ocorrida em 1930 (IGLÉCIAS, 2007, p. 77).

Observa-se, assim, que a relação entre governo e agronegócio é histórica, e as ligações entre eles foram tornando-se cada vez mais complexas, uma vez que surgiram novas entidades que representam os interesses do empresário rural, bem como aumentaram os segmentos da burocracia estatal para diferentes setores. Nesse sentido, o agribusiness possui tanto representações regionais quanto setoriais. É o caso da ABRAPA, que é uma associação nacional, que congrega associações estaduais, e cujo escopo é um setor específico da produção rural: o algodão.

\subsection{A primeira tentativa e a ABRAPA}

Fundada em 1999, a ABRAPA conta, atualmente, com nove associadas estaduais: a Abapa (Bahia), a Acopar (Paraná), a Agopa (Goiás), a Amapa (Maranhão), a Amipa (Minas Gerais), a Ampa (Mato Grosso), a Ampasul (Mato Grosso do Sul), a Apipa (Piauí) e a Appa (São Paulo). São, ao todo, mais de 1.600 produtores associados, o que representa 96\% de toda a área, 99\% da produção e $100 \%$ da exportação de algodão do Brasil ${ }^{31}$.

A associação obteve grande êxito na expansão da produtividade do algodão, pois, de acordo com dados fornecidos pela instituição, em doze anos, a área plantada duplicou (alcançou 1,07 milhão de hectares), e a produção total de pluma triplicou (alcançou um volume superior a 1,6 milhão de toneladas). A produtividade da lavoura cresceu 90\%, pois passou de $750 \mathrm{~kg} / \mathrm{ha}$ para $1.487 \mathrm{~kg} / \mathrm{ha}$, uma das maiores do mundo.

Antes de a ABRAPA ser fundada, houve uma primeira tentativa de se questionar os subsídios norte-americanos ao algodão, feita pelo Grupo Maeda, um dos maiores do ramo, com lavouras em Mato Grosso e na Bahia (estados brasileiros com grande produção cotonicultora - vide Anexo 3) . Em 1992, o grupo deu início a uma ação antidumping e a outra de direitos compensatórios, mas, de acordo com

\footnotetext{
${ }^{31}$ Vide site da ABRAPA.
} 
Jorge Maeda (2004, p. 54), ex-presidente da ABRAPA e do grupo que leva seu sobrenome, eles não contavam ainda com uma adequada representatividade do setor, além de não estarem devidamente amparados por bons profissionais; logo, a iniciativa foi frustrada. Maeda se esquece de que, além disso, a OMC estava em vias de constituição, de forma que ainda não havia, no sistema internacional, um fórum viável para contenciosos comerciais entre países. Cabe lembrar, como estudado no capítulo 1, que a sistemática do GATT-1947 não era eficiente. Maeda conta que se sentiu tão humilhado pelos norte-americanos naquela ocasião, que não conseguiu aceitar um convite para jantar na casa do embaixador brasileiro nos EUA na época, Paulo Tarso Flecha de Lima.

Pedro de Camargo Neto, ex-presidente da Sociedade Rural Brasileira (SRB), elaborou a ação de direitos compensatórios junto ao Grupo Maeda. Ele narra o quanto ficou aborrecido ao perderem a ação. Segundo ele, não foi possível demonstrar, naquele período, que o prejuízo ao setor cotonicultor brasileiro fora causado pela política norte-americana de subsídios. Para ambos, Jorge Maeda e Pedro de Camargo Neto, essa primeira tentativa serviu de aprendizado para o que deveria ser a posterior iniciativa perante a OMC (2004, p. 83 e 84).

\subsection{O Ministério da Agricultura}

Pedro de Camargo Neto ocupava o cargo de secretário de produção e comercialização do Ministério da Agricultura, Pecuária e Abastecimento (MAPA) e cuidava de algumas questões que poderiam ser solucionadas pelo Órgão de Solução de Controvérsias da OMC. No fim da década de 1990, apresentou ao ex-Ministro da Agricultura, Pratini de Moraes, o caso da soja. Já havia toda a instrução do caso, pronto para ser instaurado na OMC, quando se verificou que os preços internacionais do produto voltaram a subir, de modo que não havia mais como demonstrar o dano causado pelos subsídios à soja.

Durante o período em que se analisava a questão da soja, Pedro de Camargo solicitou a elaboração de uma nota técnica acerca do algodão, pois acreditava que era um produto com o qual também poderia se obter êxito na OMC. A nota, feita por 
Lino Colsera, também do MAPA, confirmava a problemática do algodão e a possibilidade de ser este um caso vitorioso. Assim, em 2002, o MAPA contava com três contenciosos para serem levados à OMC: a soja, o algodão e o açúcar. O Ministério das Relações Exteriores (MRE), no entanto, foi contrário aos três:

“(...) continuamos patinando na aprovação da soja e do açúcar, processos que havíamos começado em dezembro de 2001. Logo em seguida, entrou o processo do algodão e passamos a ter três. Houve uma reunião da Camex, a Câmara de Comércio Exterior, do Ministério do Desenvolvimento, em que foram apresentados pareceres do Itamaraty contra os três casos. Talvez, se tivéssemos escrito um contra parecer, pudéssemos ter aprovado naquele mesmo dia os processos". (CAMARGO NETO, 2004, p. 84)

Após essa insegurança inicial do $\mathrm{MRE}^{32}$ e após diversas outras reuniões para tratar do assunto, decidiu-se, em setembro de 2002, levar o caso do algodão adiante. Tanto o açúcar quanto a soja também foram aprovados, mas esta última, como visto acima, teve o processo prejudicado pela alta do preço do produto no cenário internacional e desistiu-se da ação na OMC.

\subsection{A articulação entre a esfera pública e a privada}

Quando, no MAPA, Pedro de Camargo apresentou o caso ao então ministro da agricultura, Pratini de Moraes, este agendou uma reunião com a ABRAPA, na qual disse que o governo demandaria os Estados Unidos na OMC, mas precisava do apoio da iniciativa privada. Em outras palavras, o ministro demonstrou como seria caro levar um caso desse adiante e precisava se certificar de que os produtores de algodão estavam dispostos a arcar com os custos. Naquela reunião, Jorge Maeda prontamente respondeu que sim e foi conversar com os demais associados: todos estavam de acordo, e as associações estaduais iriam contribuir, quanto aos custos, cada uma com seu percentual de participação na exportação do algodão. Da mesma

\footnotetext{
32 "Do ponto de vista estratégico, havia a clara percepção de que o pior cenário possível - pior ainda do que a inação - seria levar o caso à OMC e perder. Se perdêssemos, estaríamos legitimando a política agrícola norte-americana, porque, independentemente dos motivos de nossa eventual derrota, o discurso norte-americano seria: "Vocês estão reclamando dos nossos subsídios, mas foi constatado na OMC que nossa lei agrícola não tem nenhum problema, não temos de mudar nada.” Nós tínhamos, portanto, a devida preocupação com a possibilidade de perder um caso que achávamos bom, mas que apresentava várias incertezas”. (Roberto Azevêdo, 2004, p. 91)
} 
forma, o MRE também se preocupou em garantir que o setor privado manteria o suporte à ação:

"Poucas semanas depois, fizemos uma visita à Coordenação de Contenciosos do Itamaraty, ao conselheiro Roberto Azevêdo, chefe do setor, e começamos a discutir detalhes. Ele queria ter a segurança de que a Abrapa não iria esmorecer. A ação não podia começar e, de repente, o setor decidir parar, por julgar que estava custando caro. Ele lembrou que não seria bom, para o Brasil, começar e desistir. Disse ainda que seria difícil para o Brasil dar a partida na causa sem o apoio do setor, em termos de análise jurídica, legal e econômica. Eles não têm gente para fazer todos os estudos e análises que seriam necessários para termos sucesso. Naquele momento, a Abrapa comunicou ao Roberto Azevêdo que iria até o fim. Essa era a decisão, levar a questão adiante pelo menos até o fim do painel. A Abrapa daria um jeito de conseguir os recursos. Era uma associação nova, mas que, de algum jeito iria juntar esforços, e seguir adiante”. (HÉLIO TOLLINI, 2004, p. 61)

As associações estaduais do setor cotonicultor, além de contribuírem com o pagamento dos custos da ação, também tiveram muita importância no fornecimento de dados da produção estadual, bem como ao coletar testemunhos de produtores individualizados. Esses eram feitos por escrito, com firma reconhecida em cartório e, posteriormente, traduzidos para o inglês, a fim de instruir o processo. Serviram, assim, para auxiliar na comprovação do dano sofrido.

Para atuar no caso, após entrevistar oito escritórios de advocacia, tanto brasileiros quanto internacionais, a ABRAPA contratou uma firma estabelecida em Genebra, o Sidley Austin Brown \& Wood LLP - o mesmo que representara o Brasil no contencioso da Embraer. Além disso, contratou um economista, professor da Universidade da California, para elaborar um modelo econométrico. Os argumentos legais foram embasados nesse modelo, feito pelo professor Daniel Sumner ${ }^{33}$. A ABRAPA informou que, até o fechamento do painel na OMC, seus gastos com o caso do algodão tinham sido de mais de US\$ 2 milhões.

\footnotetext{
${ }^{33}$ Daniel Sumner concluiu que, se não fossem os subsídios, a produção americana, entre 1999 e 2002, teria sido $28,7 \%$ menor e a exportação teria sido reduzida em $41,2 \%$. Os preços internacionais, portanto, seriam 12,6\% mais altos. (SÉRGIO RODRIGUES COSTA e MIGUEL GARCIA BUENO, 2004, p. 40).
} 
O Ministro Celso Amorim era chefe da missão brasileira, em Genebra, no início do contencioso. Ele reconheceu o grande esforço dos produtores de algodão e afirmou, ainda, ser contrário ao imposto sobre a remessa de dinheiro para pagamento dos serviços contratados pela ABRAPA no exterior:

\begin{abstract}
"E a imprensa do mundo inteiro, inclusive jornais americanos, disse que a vitória do Brasil permite pensar o impensável: o fim dos subsídios agrícolas. E foram os produtores que bancaram isso, porque o governo brasileiro ainda não tem, infelizmente, instrumentos suficientes. Espero que tenhamos em breve. Eu acho que foi uma demonstração de coragem dos produtores. Enfrentaram inclusive obstáculos burocráticos, como ter de pagar impostos sobre remessas, que me parece uma coisa em que precisamos mexer, o que vamos tentar na Camex”. (Grifou-se) (AMORIM, 2004, p. 131)
\end{abstract}

Dessa forma, a cooperação entre o setor governamental e o setor privado foi fundamental ao desenvolvimento do contencioso do algodão e favoreceu o alcance do êxito na decisão final do OSC.

Robert Putnam (1998) discorre acerca da teoria dos jogos em dois níveis, segundo a qual o comportamento dos negociadores internacionais relaciona-se aos grupos de pressão que atuam sobre eles, de modo a influenciar o processo de tomada de decisões. No caso do algodão, conforme narrado neste capítulo, os produtores, representados pela ABRAPA e por um ex-presidente da SRB, foram responsáveis pela decisão governamental, tanto do MAPA quanto do MRE, de submeter a questão à OMC.

\title{
3.5. Continuidade da política externa brasileira
}

Para Amado Cervo (2003, p. 344), ao citar Celso Lafer $^{34}$, as categorias explicativas da identidade nacional brasileira minimizam o papel dos regimes políticos como definidores da política externa do país. Um desses aspectos, para Cervo, seria o legado histórico da diplomacia brasileira, o qual demonstra a

\footnotetext{
${ }^{34}$ Para Lafer, a identidade brasileira é uma categoria explicativa de tendências e mudanças em política externa e apresenta cinco componentes: o legado histórico, o contexto dos países-vizinhos, a inserção assimétrica de uma potência média, o desenvolvimento como vetor de seus objetivos de política externa e o processo de abertura externa desde 1990. (LAFER, Celso. A identidade internacional do Brasil e a política externa brasileira: passado, presente e futuro.São Paulo: Perspectiva, 2001).
} 
continuidade em política externa, mesmo com mudanças de regimes e governos. $\mathrm{O}$ caso do algodão não foi diferente. Iniciou-se no governo do ex-presidente Fernando Henrique Cardoso (FHC) e teve a devida continuidade com o governo de Luís Inácio Lula da Silva.

No governo FHC, houve a criação da Coordenação-Geral de Contenciosos (CGC) do Itamaraty ${ }^{35}$, cujo propósito era acompanhar, de forma mais especializada, as etapas precedentes e as propriamente contenciosas na OMC, além daquelas sob a égide do mecanismo de solução de controvérsias do Mercosul. Houve, assim, de acordo com Schimanski (2006, p. 59), um claro compromisso com o reforço da capacidade brasileira de promover seus interesses no cenário internacional.

Embora houvesse a insegurança inicial do MRE, passada essa primeira fase de cálculo político, o Itamaraty defendeu a causa do setor cotonicultor com ênfase. Todos os relatos de integrantes do corpo diretivo da ABRAPA, no período de implementação do caso, são unânimes em afirmar o apoio recebido por Roberto Azevêdo, que, na época, ocupava justamente o cargo de coordenador de contenciosos do Ministério. O diplomata foi determinante, também, para o argumento brasileiro de confrontar a Cláusula de Paz do Acordo sobre Agricultura da $\mathrm{OMC}^{36}$.

Quando houve a mudança de governo, os produtores de algodão ficaram preocupados com a possibilidade de haver alguma solução de continuidade no caso, pois haviam despendido muitos recursos nele, não apenas financeiros, mas, principalmente, esforços para conseguir todas as informações solicitadas para a montagem do painel e até mesmo esforços políticos para angariar apoio à causa. Dessa forma, procuraram assegurar a continuidade do contencioso na OMC. O depoimento abaixo é de Helio Tollini, diretor-executivo da ABRAPA:

\footnotetext{
${ }^{35}$ Schimanski (2006, p. 59) informa que o Decreto 3.959, de 10 de outubro de 2001, reestruturou a área econômico-comercial do Itamaraty e implantou a CGC, subordinada ao Departamento Econômico (DEC).

36 “Roberto Azevêdo insistiu que precisávamos contornar as restrições advindas da Cláusula da Paz ou não conseguiríamos abrir o processo. Ele corretamente insistiu para que reuníssemos o máximo de informações e de fatos que demonstrassem, sem a menor sombra de dúvida, que os subsídios americanos de 1999 a 2002 haviam ultrapassado os níveis previstos para o algodão em 1992, o que era proibido pela Cláusula da Paz”. (Scott Andersen, 2004, p. 117 e 118)
} 
"O novo ministro da Agricultura, Roberto Rodrigues, do governo Lula, apoiou desde o início a ação. O novo ministro das Relações Exteriores, Celso Amorim, conhecia bem todo o caso, por ter sido chefe da missão duas vezes. Os produtores ficaram na expectativa, quando da eleição do presidente Lula, porque era possível imaginar algumas razões pelas quais o novo governo poderia preferir não mexer com isso. Afinal, era uma ação difícil. No fundo, achava-se que o governo Lula iria continuar o processo e apoiar a ação, mas era preciso ouvir isso de alguém. Estávamos trabalhando, gastando dinheiro e queríamos saber se continuaríamos em frente. No fim das contas, soubemos que a luta continuaria”. (TOLLINI, 2004, p. 63 e 64)

Logo, o novo governo nunca hesitou em levar a causa adiante. Ao contrário, o governo Lula da Silva aprimorou a participação brasileira em fóruns multilaterais, como a própria OMC, e tem buscado inserir o país internacionalmente de uma forma madura, para que o Brasil seja, cada vez mais, um verdadeiro global player no cenário internacional.

Essa análise corrobora o estudo paradigmático feito por Amado Cervo (2008), com relação à inserção internacional brasileira ao longo da história. Ele apresenta quatro paradigmas: o liberal-conservador (de 1800 a 1930), o desenvolvimentista (de 1930 a 1989), o neoliberal (ou normal, de 1990 a 2002) e, por fim, o logístico (a partir de 2002). Embora não seja escopo desse trabalho tal estudo, discorreremos brevemente sobre os dois últimos paradigmas, uma vez que tratam dos dois governos aqui analisados e atuantes no caso do algodão: FHC e Lula da Silva.

A década de 1980 foi chamada de “a década perdida”, em razão dos problemas econômicos enfrentados na América Latina. O Brasil, na década de 1970, havia vivido o “milagre econômico”, período de grande crescimento, porém o qual veio acompanhado por alta dívida externa. Assim, quando do segundo choque do petróleo, os Estados Unidos aumentaram sua taxa de juros, o que agravou o problema da dívida, levando muitos países à situação de crise econômica. O México decretou sua moratória em 1982, e o Brasil passou por vários planos heterodoxos, como foi o caso do congelamento de preços, feito pelo governo Sarney, a fim de combater a inflação. Desse modo, a década de 1980 foi o 
fim do modelo de industrialização por substituição de importações, que marcara o paradigma desenvolvimentista.

O país adentrou, então, no paradigma neoliberal, ou normal - termo cunhado pelo ex-ministro argentino, Domingos Cavallo, que representava a submissão dos países latino-americanos aos ditames neoliberais. O “Consenso de Washington” determinava que os países liberalizassem suas economias e, no caso dos países em desenvolvimento, que estavam em crise, deveriam promover ajustes macroeconômicos prescritos pelo Fundo Monetário Internacional (FMI).

No Brasil, o Estado neoliberal foi implantado no governo Collor e consolidado com Fernando Henrique Cardoso. Segundo Cervo (2008), esse período não significou uma inserção internacional madura, pois a abertura econômica foi indiscriminada e, em vez de equilibrar as contas com o exterior, aprofundou as dependências estruturais do país. No final do governo de Fernando Henrique Cardoso, entretanto, o atual paradigma de política externa teve início, para firmarse, então, no governo Lula da Silva.

Trata-se do paradigma logístico, em que há uma recuperação da autonomia decisória do processo de política externa e há interdependência, com o objetivo de superar assimetrias entre os países. O Brasil passa, no novo século, a fazer valer seus recursos de poder, e o Estado passa a ter capacidade empresarial, sendo capaz de internacionalizar sua economia.

Diante de tais paradigmas, conclui-se que a continuidade dada pelo governo Lula da Silva ao caso do algodão decorre do fato de o mesmo ser uma decisão de política externa do final do governo FHC, ou seja, quando este já buscava adentrar ao paradigma logístico e deixar de lado o paradigma neoliberal. O novo conceito requer que o Estado dialogue com os empresários domésticos e busque fortificar seus interesses e defendê-los no meio internacional. Por isso, o governo Lula da Silva não apenas manteve a causa na OMC, mas também a aprofundou, como demonstra a recente publicação da Medida Provisória (MP) $n^{0}$ 482, de 10 de fevereiro de 2010. 


\subsection{Sobre a Medida Provisória $n^{\circ}$ 482/10}

A $\mathrm{MP}^{37}$ é consequência direta do caso do algodão. Ela dispõe sobre medidas de suspensão de concessões ou outras obrigações do país relativas aos direitos de propriedade intelectual e outros, em casos de descumprimento de obrigações do Acordo Constitutivo da Organização Mundial do Comércio - OMC. Promulgá-la foi, também, uma decisão que envolveu a coordenação entre o governo e os produtores de algodão.

No momento em que houve a vitória brasileira, começaram as discussões sobre como seria implementada a decisão da OMC. Desde o primeiro instante em que se falou acerca da possibilidade de retaliação cruzada, surgiram muitos críticos, receosos do impacto político que tal atitude poderia ter. Os produtores de algodão não faziam oposição a beneficiar outros setores da economia brasileira, desde que eles também fossem beneficiados, o que é justo, afinal foram os responsáveis pelos custos da ação na OMC.

Assim, ao analisar a lista de produtos sujeitos ao aumento de $\operatorname{tarifas}^{38}$, verifica-se que produtos estrangeiros, relacionados ao algodão e ao setor têxtil, serão taxados em $100 \%$. Na média, entretanto, ao analisar todos os produtos da lista, a taxa é em torno de 40\%. É natural, como visto nesse trabalho, pelos esforços empreendidos pela ABRAPA, que os bens concernentes ao mercado cotonicultor tivessem uma tarifa maior.

A lista inclui arenque, cerejas, batatas, trigo, xampus, pasta de dentes e gomas de mascar. O diretor do Departamento de Economia do MRE, Carlos Márcio Cozendey, explicou que o governo resolveu incluir outros setores, além do agrícola, para despertar interesse de industriais norte-americanos que não se beneficiam do algodão, de modo que estes também pressionem o Congresso dos EUA a alterar a política de subsídios. A retaliação tem prazo de 30 dias para ser aplicada e as novas

\footnotetext{
${ }^{37}$ Disponível no site da Presidência da República.

${ }^{38}$ Lista liberada pela Câmara de Comércio Exterior (Camex) em 08 de março de 2010.
} 
alíquotas do Imposto de Importação para as mercadorias escolhidas pela CAMEX têm vigência de um ano. (AGÊNCIA BRASIL, 2010)

A presente monografia é finalizada em março de 2010, e a última notícia acerca do caso refere-se à possibilidade de a CAMEX complementar a lista divulgada, em 08 de março de 2010, com direitos de propriedade intelectual. Para isso, haverá consulta pública acerca de vinte e uma medidas, pelo prazo de vinte dias. As sugestões poderão ser enviadas ao governo por carta ou pela internet.

Esse fato - as consultas públicas - já representa uma necessidade de as decisões em política externa estarem em conformidade com a opinião dos mais diversos setores da sociedade brasileira. Assim, podemos responder às perguntas feitas na introdução desse trabalho: a participação de atores não-governamentais, no painel do algodão, foi determinante para a vitória brasileira? Em caso positivo, tal participação significaria maior democratização da política externa brasileira?

\subsection{Democratização e Política Externa}

Com relação à primeira pergunta formulada, ela já foi respondida ao longo desse trabalho. Toda a narrativa desse terceiro capítulo demonstra a forte atuação da ABRAPA no caso do algodão. É impossível pensar que os subsídios norteamericanos ao algodão poderiam ser questionados na OMC se contassem apenas com a atuação governamental.

O empresário cotonicultor foi indispensável para que o caso fosse bemsucedido na OMC, pois custeou a ação, forneceu testemunhos, provas, documentos e informações necessárias para a formação do argumento jurídico. O governo isolado não teria os mesmos meios de atuação.

Além do agronegócio do algodão, houve a importante participação de algumas organizações não-governamentais (ONGs), cuja dimensão, apenas mencionada nesse trabalho, será agora brevemente demonstrada.

\subsubsection{A participação das organizações não-governamentais}


A OXFAM Internacional é uma ONG dedicada a erradicar a pobreza mundial. Ela reúne quatorze organizações localizadas em diferentes partes do globo $^{39}$. Foi instituída em 1995 e seu nome deriva de Oxford Committee for Famine Relief, uma de suas entidades fundadoras, criada em 1942, na Inglaterra.

Como o problema do algodão afetava sobremaneira países africanos, a OXFAM elaborou um relatório denominado Cultivating poverty: the impact of US cotton subsidies e o publicou em 27 de setembro de 2002 - a mesma data em que o Brasil iniciou o procedimento de consultas na OMC.

O relatório teve grande impacto, porquanto demonstrou a miséria causada aos países cuja economia era dependente da exportação de algodão. De acordo com dados de 2008, fornecidos pela OXFAM, a África Ocidental produz 5\% de algodão do mundo e é responsável por $15 \%$ do comércio global da fibra de algodão. Os estudos da entidade demonstraram que a retirada dos subsídios norte-americanos ao algodão representaria um incremento da ordem de US\$ 1 bilhão, em termos de receita de exportação, para os países daquela região.

Além da OXFAM, uma ONG norte-americana, o International Food Policy Research Institute, estimou que o efeito dos subsídios sobre o preço internacional do algodão foi responsável por aumentar em cerca de 90 mil pessoas o número de habitantes que viviam abaixo da linha de pobreza no Benin, entre 2001 e 2002 (COSTA e BUENO, 2004, p. 27).

Em maio de 2003, Benin, Chad, Mali e Burkina Faso lançaram a chamada Cotton Initiative, com o intuito de batalhar pela redução dos subsídios norteamericanos ao algodão, que tantos males causou a esses países. Por causa dessas iniciativas, o Banco Mundial também teve participação importante, ao elaborar alguns relatórios sobre a questão do algodão no mundo.

A relevância em descrever tais ações está no fato de muitos céticos questionarem a postura brasileira de desafiar o gigante norte-americano, mas o relato

\footnotetext{
${ }^{39}$ Austrália, Bélgica, Canadá, França, Alemanha, Grã-Bretanha, Hong Kong, Irlanda, México, Países Baixos, Nova Zelândia, Quebec, Espanha e Estados Unidos.
} 
acima prova que a problemática do algodão é muito maior do que uma disputa comercial entre duas nações, e o Brasil possui, assim, muitos aliados para auxiliá-lo a implementar as normativas da OMC.

\subsubsection{Aumento da democratização?}

Após a clara resposta à primeira pergunta desse trabalho, em que confirmamos a relevância dos atores não-governamentais para a vitória brasileira, cabe responder à segunda questão. Essa é uma pergunta mais difícil de ser respondida, porquanto há a necessidade de um estudo mais aprofundado acerca do conceito de democracia. Afinal, o que é democracia para alguns não o é para outros.

Como não é escopo dessa monografia dissertar sobre conceitos de democracia, deve-se analisar a pergunta formulada na introdução, a partir da análise mais tradicional do termo democracia, isto é, a participação e o envolvimento do maior número de atores sociais. Nesse sentido, é possível responder afirmativamente à questão, ainda que de forma cautelosa.

Alguns autores consideram que, por uma perspectiva histórica, houve o insulamento do corpo diplomático brasileiro, a fim de que decisões em política externa pudessem ser tomadas sem ingerências externas (DAWISSON LOPES, 2008, p. 108). O caso do algodão, entretanto, demonstra que o setor privado foi determinante no processo decisório para levar o caso adiante.

Poder-se-ia contra-argumentar com a afirmativa de que empresários rurais, se

não tivessem dinheiro, não teriam a influência devida na tomada de decisão. É claro que os recursos financeiros do setor foram relevantes - pois o caso precisava ser custeado -, mas, mais do que eles, a organização dos produtores de algodão, simbolizada pela ABRAPA, foi o principal fator responsável pelo convencimento do Itamaraty de que o caso iria para frente. Dessa forma, a democratização em política 
externa parece estar atrelada à capacidade que outros setores da sociedade têm de se organizar, para buscar seus interesses ${ }^{40}$.

Para Maria Izabel Valladão de Carvalho (2001), a redemocratização, a abertura da economia e os desafios da estabilidade monetária contribuem para que outras instâncias governamentais e diferentes agentes sociais e políticos tenham um papel mais efetivo no processo decisório da política exterior brasileira. A maior interdependência entre os Estados e as sociedades, bem como os constrangimentos mais intensos das decisões originadas no âmbito internacional, sobre os interesses domésticos no mundo globalizado, constituem poderosos incentivos para que as questões de política externa extrapolem o nível do governo e mobilizem a sociedade.

Desse modo, apesar de alguns autores terem defendido a existência de autonomia do MRE na condução de política externa - como foi o caso de Maria Regina Soares de Lima (2000), que já afirmou haver uma “delegação tácita” de setores interessados para que o Itamaraty conduzisse as ações no plano externo -, notam-se algumas mudanças na postura dos setores privados. A análise do caso do algodão auxilia a evidenciar estas alterações.

${ }^{40}$ Nesse sentido, ver Andrew Moravcsik, 1997. 


\section{CONCLUSÃO}

O presente trabalho analisou o contencioso do algodão na OMC. Por meio da metodologia de estudo de caso, foi proposto, na parte introdutória, responder a duas questões. A primeira delas refere-se à possibilidade de a participação do setor nãogovernamental ser determinante à vitória brasileira na OMC. A segunda pergunta indaga se, de fato, há certa democratização da política exterior do país. Para alcançar uma resposta, o trabalho foi estruturado em três capítulos.

No primeiro, tratou-se do funcionamento da OMC e de seus órgãos. Também se discorreu acerca de suas diferenças com o Gatt-1947 e acerca das rodadas multilaterais de comércio. Deu-se ênfase ao Órgão de Solução de Controvérsias da organização. Foi visto que, na década de 1990, apesar de os Estados Unidos emergirem da Guerra Fria como potência hegemônica, dividiam, no campo comercial, a importância com outros países. Houve, assim, a necessidade de uma verdadeira instituição que contemplasse os interesses comerciais dos diferentes Estados. Surgia a OMC que, diferentemente do sistema contemplado pelo Gatt-1947, tem um mecanismo de solução de controvérsias cujas decisões são tomadas por consenso negativo. Isso tornou o sistema mais justo e eficaz.

No segundo capítulo, analisaram-se aspectos mais técnicos do contencioso do algodão. Foram vistos os argumentos legais utilizados pela defesa brasileira, como o fato de a Cláusula de Paz do Acordo sobre Agricultura não impedir a propositura de ação, os pagamentos diretos feitos pelos EUA não serem subsídios constantes da Caixa Verde, o programa norte-americano Step 2 ser ilegal, os subsídios ao algodão terem causado sérios danos ao Brasil e o fato de os programas de garantia à exportação dos EUA não estarem em conformidade com as normas da OMC. Discorreu-se, dessa forma, acerca do Acordo sobre Subsídios e Medidas Compensatórias e o Acordo sobre Agricultura da OMC, além de tratar da Farm Bill, a lei agrícola norte-americana. Foram apresentadas as decisões do painel e do Órgão de Apelação. 
No terceiro capítulo, tratou-se da articulação entre a esfera privada e a pública para levar o caso adiante. Discorreu-se acerca do agronegócio brasileiro e da importante participação da ABRAPA. Também se falou sobre o relatório da OXFAM Internacional, publicado no mesmo dia em que o Brasil deu início ao caso na OMC, e sobre a Cotton Initiative, um grupo de países africanos que sofreu graves prejuízos com os subsídios ao algodão.

Da análise do caso, foi possível concluir que o êxito brasileiro, na OMC, vincula-se à participação dos atores não-governamentais. A ABRAPA foi responsável pelo financiamento da causa, pela obtenção de provas (como testemunhos e outros documentos que comprovaram os efeitos distorcivos dos subsídios norte-americanos) e pela persistência junto ao governo de que o Brasil poderia vencer. A OXFAM Internacional, o grupo Cotton Initiative e o International Food Policy Research Institute ofereceram importantes informações comprobatórias do dano causado pelos subsídios, não apenas ao comércio internacional, mas também por aumentar a miséria de algumas populações do globo. Dessa forma, a primeira pergunta formulada na introdução foi respondida afirmativamente.

A partir da constatação de que a vitória brasileira dificilmente seria alcançada sem o envolvimento de atores não-estatais, fez-se a análise da segunda questão, concernente ao aumento da democratização da política externa brasileira. Observouse que, ao se considerar democracia no sentido de pluralidade de atores no processo decisório, é possível falar em maior democratização da política exterior. Logo, também a segunda pergunta foi respondida de modo afirmativo.

Assim, conforme exposto no último capítulo, apesar de parte da literatura considerar o Ministério das Relações Exteriores autônomo na condução da política externa brasileira, o caso do algodão demonstrou que o processo decisório tem sido mais diversificado e que, se não fosse pela participação de outros setores, o Brasil não tomaria a decisão de submeter o caso à OMC. Dessa forma, as parcerias entre o governo e os grupos de interesse tornam-se cada vez mais importantes ao objetivo de o país se firmar como grande interlocutor no cenário internacional. 
Com base no estudo realizado, foi possível concluir que o nível de organização de um grupo de interesse é o fator responsável pela sua capacidade de influenciar a tomada de decisão em política externa. Há, portanto, democratização e diminuição da apatia em assuntos concernentes à política exterior. A ampliação da participação dos atores capazes de atuar no processo decisório, entretanto, depende do potencial desses grupos de se organizar, com o intuito de levar o governo a agir em conformidade com seus interesses. 


\section{REFERÊNCIAS BIBLIOGRÁFICAS}

AGÊNCIA BRASIL. Camex libera lista de produtos que Brasil vai sobretaxar para retaliar subsídio americano ao algodão. Disponível em: <http://www.agenciabrasil.gov.br > Acesso em março/2010.

ALMEIDA, Paulo Roberto de e BARBOSA, Rubens Antônio. Relações BrasilEstados Unidos: assimetrias e convergências. São Paulo: Saraiva, 2006.

BAFFES, John. The cotton problem. Relatório do Trade Department - The World Bank. Washington, 2004.

BARRAL, Welber Oliveira. O Brasil e a OMC. Curitiba: Juruá, 2002.

BARRAL, Welber Oliveira. O comércio internacional. Belo Horizonte: Del Rey, 2007.

CAI, Phoenix. Think big and ignore the law: US corn and ethanol subsidies and WTO law. Georgetown Journal of International Law, vol. 40, 2009.

CARVALHO, Maria Izabel Valladão de. O Itamarati, os empresários e a política exterior do Brasil. Meridiano 47, $\mathrm{n}^{\circ} 7$, jan./2001.

CERVO, Amado Luiz. Political Regimes and Brazil's Foreign Policy. In: SARAIVA, José Flávio Sombra (ed.). Foreign Policy and Political Regime. Brasília: IBRI, 2003.

CERVO, Amado Luiz. Inserção Internacional: formação dos conceitos brasileiros. São Paulo: Saraiva, 2008.

COSTA, Sérgio Rodrigues e BUENO, Miguel Garcia (orgs.) A saga do algodão: das primeiras lavouras à ação na OMC. Rio de Janeiro: Insight Engenharia,2004.

FOLHA DE SÃO PAULO. OMC espera concluir rodada Doha em 2010. Disponível em: <http://www1.folha.uol.com.br/folha/dinheiro/ult91u618811.shtml> Acesso em Nov/2009.

HILL, Cristopher. The changing politics of foreign policy. New York: Palgrave Macmillan, 2003.

HIRST, Monica e SOARES DE LIMA, Maria Regina. Contexto internacional, democracia e política externa. Política Externa, vol. 11, n² 2, set./nov. 2002.

HUDEK, Robert. A statistical profile of GATT Dispute Settlement Cases. Minnesota Journal Global of Trade, vol. 2, 1993.

IGLÉCIAS, Wagner. O empresariado do agronegócio no Brasil: ação coletiva e formas de atuação política - as batalhas do açúcar e do algodão na OMC. Revista de Sociologia Política, nº 28, Curitiba, jun/2007. 
JACKSON, John H. The jurisprudence of GATT and the WTO: insights on treaty law and economic relations. New York: Cambridge University Press, 2000.

JACKSON, John H. The World Trading System. Cambridge: The MIT Press, 1992.

JACKSON, John H. Reflections on International Economic Law. University of Pennsylvania Journal of International Economic Law, vol. 17, ${ }^{\circ}{ }^{\circ}, 1996$.

KEOHANE, Robert e MILNER, Helen (eds.) Internationalization and domestic politics. Cambridge: Cambridge University Press, 1996.

LAFER, Celso. A OMC e a regulamentação do comércio internacional: uma visão brasileira. Porto Alegre: Livraria do Advogado, 1998.

LIMA, Maria Regina Soares de. Instituições democráticas e política exterior. Contexto Internacional, Rio de Janeiro, vol. 22, $\mathrm{n}^{\circ}$ 2, jul./dez. 2000.

LIMA, Thiago. $O$ contencioso do algodão: cenários para mudança na política de subsídios dos EUA. Revista Brasileira de Política Internacional, vol. 49, n ${ }^{\circ}$, jan.jun./2006.

LOPES, Dawisson Belém. A plausibilidade de uma gestão democrática da política externa: algumas hipóteses (insatisfatórias) sobre o caso brasileiro. Cena Internacional, vol. 10, $\mathrm{n}^{\mathrm{o}}$ 2, 2008.

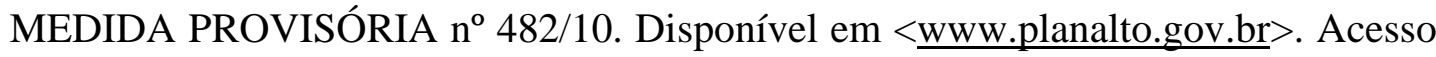
em março/2010.

MILNER, Helen V. Interest, institutions and information. Domestic politics and international relations. Princeton: Princeton University Press, 1997.

Ministério do Desenvolvimento, Indústria e Comércio (MDIC). Disponível em: $<$ http://www.mdic.gov.br/sitio/interna/interna.php?area=5\&menu=37> Acesso em Nov/2009.

MORAVCZIK, Andrew. Taking Preferences Seriously: a liberal theory of international politics, v. 51, n. 4. Autumn, 1997.

MRE. Nota à imprensa de 03 de março de 2005. Contencioso Brasil-Eua sobre subsídios ao algodão. Disponível em: Repertório de política externa: posições do Brasil. Brasília: Fundação Alexandre de Gusmão, 2007.

NARLIKAR, Amrita. International Trade and Developing Countries: Bargaining Coalitions in the GATT and WTO. Routledge, 2004.

NASH, John D. e INGCO, Merlinda D. Agriculture and the WTO - Creating a trading system for development. USA: The World Bank and Oxford University Press, 2004. 
NASSER, Rabih Ali. A OMC e os países em desenvolvimento. São Paulo: Aduaneiras, 2002.

OLIVEIRA, Marcelo Fernandes de. Multilateralismo, democracia e política externa no Brasil: contenciosos das patentes e do algodão na OMC. Contexto Internacional, Rio de Janeiro, vol. 29, nº 1, jan-jun/2007.

OMC. Agreement on Agriculture. Disponível em: < http://www.wto.org/english/res_e/booksp_e/analytic_index_e/agriculture_01_e.htm> Acesso em setembro/2009.

OMC. Agreement on Subsidies and Countervailing Measures. Disponível em: < http://www.wto.org/english/docs_e/legal_e/24-scm_01_e.htm_>Acesso em setembro/2009.

OMC. Dispute cases involving Brazil. Disponível em: <http://www.wto.org/english/thewto_e/countries_e/brazil_e.htm> Acesso em novembro/2009.

OMC. DS 267. Disponível em: <http://www.wto.org/english/ tratop_e/dispu_e/cases_e/ds267_e.htm> Último acesso em março/2010.

OMC. Understanding on Rules and Procedures Governing the Settlement of Disputes. Disponível em: < http://www.wto.org/english/docs_e/legal_e/28dsu_e.htm>. Acesso em novembro/2009.

OXFAM, 2004. Finding the moral fiber. Why reform is urgently needed for a fair cotton trade. Outubro de 2004 (Oxfam briefing paper, $n^{\circ}$ 69).

PEREIRA, Ana Cristina Paulo. Solução de controvérsias na OMC: teoria e prática. In: PEREIRA, Ana Cristina Paulo (org.). Direito Internacional do Comércio: mecanismo de solução de controvérsias e casos concretos na OMC. Rio de Janeiro: Lúmen Juris, 2003.

PETERSMANN, Ernest-Ulrich. The GATT/WTO Dispute Settlement System. London: Kluwer Law International, 1997.

PUTNAM, Robert. Diplomacy and domestic politics: The logic of two level games. International Organization, vol. 42, nº 3, 1998.

ROSENTHAL, Paul C. e VERMYLEN, Robert T. C. The WTO Antidumping and Subsidies Agreements: did the United States achieve its objectives during the Uruguay Round? Disponível em: <http://scholar.google.com.br/scholar?q=info:otfW2xjX6mYJ:scholar.google.com/\& hl=pt-BR\&lr=\&output=viewport\&shm=1\&pg=1> Acesso em julho/ 2008.

SATO, Eiiti. De Gatt para a OMC e a agenda do Brasil no comércio internacional. In: ALTEMANI, Henrique e LESSA, Antônio Carlos (orgs.). Relações Internacionais do Brasil - Temas e Agendas. vol. 2, São Paulo: Saraiva, 2006. 
SCHIMANSKI, Silvana. O contencioso sobre os subsídios ao algodão entre Brasil e Estados Unidos na Organização Mundial do Comércio (2002-2005). Dissertação de Mestrado. UFRGS, Porto Alegre: 2006.

STRATFOR. Brazil, US: an intellectual property precedent. Disponível em $<$ www.stratfor.com $>11$ de fevereiro de 2010.

THE ECONOMIST. So near and yet so far. The Economist print edition. 31 de julho de 2008.

THE WALL STREET JOURNAL. Cotton clubbed. Disponível em: < http://online.wsj.com/article/SB121253535297643105.html?mod=opinion_main_rev iew_and_outlooks $>$ Acesso em julho/2008.

THORSTENSEN, Vera. OMC - Organização Mundial do Comércio: as regras do comércio internacional e a nova rodada de nogociações multilaterais. 2 ed. São Paulo: Aduaneiras, 2001.

VALOR ECONÔMICO. MP prevê retaliação em propriedade intelectual. Disponível em $<\underline{\text { www.valoronline.com.br }}>$ Acesso em fevereiro/2010.

VIGEVANI, Tullo. $\mathbf{O}$ contencioso Brasil $\mathbf{x}$ Estados Unidos da Informática: uma análise sobre formulação da política exterior. São Paulo: Editora AlfaOmega/Edusp, 1995.

VIZENTINI, Paulo Fagundes. O G3 e o G20 - o Brasil e as novas coalizões internacionais. In: ALTEMANI, Henrique e LESSA, Antônio Carlos (orgs.). Relações Internacionais do Brasil - Temas e Agendas. vol. 2, São Paulo: Saraiva, 2006.

YIN, Robert K. Case study research: design and methods. London: Sage Publications, 1994. 
ANEXO 1 - Acordos da Rodada Uruguai

Declaração de Marraqueshe, de 15 de abril de 1994.

Ato Final

Acordo que estabelece a Organização Mundial do Comércio

Anexo 1

Anexo 1A Multilateral Agreements on Trade in Goods

- GATT 1994

(Must be read with GATT 1947)

- Agriculture

- Sanitary and Phytosanitary

- Textiles and Clothing

- Technical Barriers to Trade-Related Investment Measures (TRIMs)

- Anti-dumping (Article VI of GATT 1994)

- Customs valuation (Article VII of GATT 1994)

- Preshipment Inspection

- Rules of Origin

- Import Licensing

- Subsidies and Countervailing Measures

- Safeguards

Anexo 1B General Agreement on Trade in Services (GATS)

Anexo 1C Trade-Related Aspects of Intellectual Property Rights (TRIPS)

Anexo 2 Dispute Settlement Understanding

Anexo 3 Trade Policy Review Mechanism

\section{Anexo 4 Plurilateral Trade Agreements}

- Anexo 4(a) Agreement on Trade in Civil Aircraft

- Anexo 4(b) Agreement on Government Procurement

- Anexo 4(c) International Dairy Agreement Anexo 4(d) International Bovine Meat Agreement 
ANEXO 2 - Estrutura da OMC

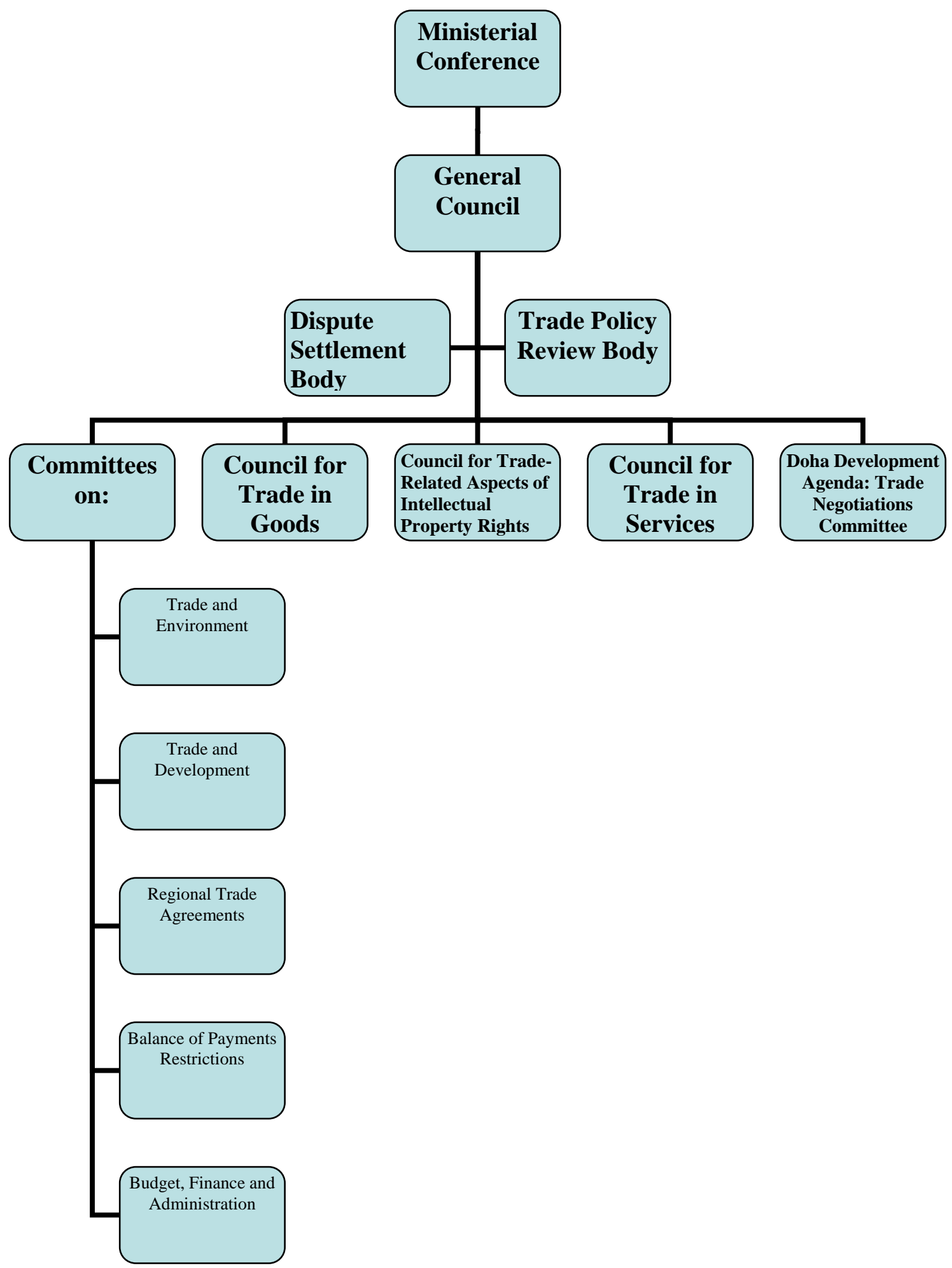




\section{ANEXO 3 - Comparativo de área, produtividade e produção do algodão em pluma no Brasil}

Quadro 5

ALGODÃO EM PLUMA

COMPARATIVO DE ÁREA, PRODUTIVIDADE E PRODUÇÃO

SAFRAS 2008/2009 E 2009/2010

\begin{tabular}{|c|c|c|c|c|c|c|c|c|c|}
\hline \multirow[b]{2}{*}{ REGIÃO/UF } & \multicolumn{3}{|c|}{ ÁREA (Em mil ha) } & \multicolumn{3}{|c|}{ PRODUTIVIDADE (Em kg/ha) } & \multicolumn{3}{|c|}{ PRODUÇÄO (Em mil t) } \\
\hline & $\begin{array}{c}\text { Safra } 08 / 09 \\
\text { (a) }\end{array}$ & $\begin{array}{c}\text { Safra } 09 / 10 \\
\text { (b) }\end{array}$ & $\begin{array}{c}\text { VAR. } \% \\
\text { (b/a) }\end{array}$ & $\begin{array}{l}\text { Safra } 08 / 09 \\
\text { (c) }\end{array}$ & $\begin{array}{c}\text { Safra } 09 / 10 \\
\text { (d) }\end{array}$ & $\begin{array}{c}\text { VAR. } \% \\
\text { (d/c) }\end{array}$ & $\begin{array}{c}\text { Safra } 08 / 09 \\
\text { (e) }\end{array}$ & $\begin{array}{l}\text { Safra } 09 / 10 \\
\text { (f) }\end{array}$ & \begin{tabular}{|c} 
VAR. $\%$ \\
(f/e)
\end{tabular} \\
\hline NORTE & 2,8 & 3,7 & 32,1 & 1.229 & 1.455 & 18,4 & 3,4 & 5,4 & 58,8 \\
\hline TO & 2,8 & 3,7 & 32,1 & 1.229 & 1.455 & 18,4 & 3,4 & 5,4 & 58,8 \\
\hline NORDESTE & 330,8 & 309,5 & $(6,4)$ & 1.228 & 1.452 & 18,2 & 406,2 & 449,2 & 10,6 \\
\hline MA & 12,8 & 11,5 & $(10,3)$ & 1.247 & 1.444 & 15,8 & 16,0 & 16,6 & 3,8 \\
\hline PI & 11,2 & 7,6 & $(32,1)$ & 1.163 & 1.242 & 6,8 & 13,0 & 9,4 & $(27,7)$ \\
\hline $\mathrm{CE}$ & 3,8 & 3,8 & - & 252 & 261 & 3,6 & 1,0 & 1,0 & - \\
\hline $\mathrm{RN}$ & 9,0 & 9,0 & - & 177 & 272 & 53,7 & 1,6 & 2,4 & 50,0 \\
\hline PB & 5,2 & 5,2 & - & 245 & 287 & 17,1 & 1,3 & 1,5 & 15,4 \\
\hline $\mathrm{PE}$ & 2,5 & 2,5 & - & 248 & 251 & 1,2 & 0,6 & 0,6 & - \\
\hline $\mathrm{AL}$ & 3,1 & 3,1 & - & 79 & 118 & 49,4 & 0,2 & 0,4 & 100,0 \\
\hline BA & 283,2 & 266,8 & $(5,8)$ & 1.315 & 1.564 & 18,9 & 372,5 & 417,3 & 12,0 \\
\hline CENTRO-OESTE & 481,6 & 482,6 & 0,2 & 1.591 & 1.558 & $(2,1)$ & 766,4 & 751,9 & $(1,9)$ \\
\hline MT & 387,4 & 392,4 & 1,3 & 1.585 & 1.550 & $(2,2)$ & 614,2 & 608,3 & $(1,0)$ \\
\hline MS & 36,9 & 35,8 & $(3,0)$ & 1.550 & 1.540 & $(0,6)$ & 57,2 & 55,1 & $(3,7)$ \\
\hline GO & 57,3 & 54,4 & $(5,0)$ & 1.658 & 1.626 & $(1,9)$ & 95,0 & 88,5 & $(6,8)$ \\
\hline SUDESTE & 22,5 & 21,6 & $(4,0)$ & 1.448 & 1.459 & 0,8 & 32,6 & 31,5 & $(3,4)$ \\
\hline MG & 15,3 & 15,1 & $(1,3)$ & 1.461 & 1.476 & 1,0 & 22,4 & 22,3 & $(0,4)$ \\
\hline $\mathrm{SP}$ & 7,2 & 6,5 & $(10,0)$ & 1.421 & 1.421 & - & 10,2 & 9,2 & $(9,8)$ \\
\hline SUL & 5,5 & 0,2 & $(96,4)$ & 923 & 821 & $(11,1)$ & 5,1 & 0,2 & $(96,1)$ \\
\hline PR & 5,5 & 0,2 & $(96,0)$ & 923 & 821 & $(11,1)$ & 5,1 & 0,2 & $(96,1)$ \\
\hline NORTE/NORDESTE & 333,6 & 313,2 & $(6,1)$ & 1.228 & 1.452 & 18,2 & 409,6 & 454,6 & 11,0 \\
\hline CENTRO-SUL & 509,6 & 504,4 & $(1,0)$ & 1.578 & 1.554 & $(1,5)$ & 804,1 & 783,6 & $(2,5)$ \\
\hline BRASIL & 843,2 & 817,6 & $(3,0)$ & 1.439 & 1.515 & 5,3 & $1.213,7$ & $1.238,2$ & 2,0 \\
\hline
\end{tabular}

Fonte: Conab (2010) 
ANEXO 4 - Balança Comercial Brasileira do Algodão (Fev. 2009/2010)

\begin{tabular}{|l|l|l|c|}
\hline ALGODÃo & Fevereiro/2010 & Fevereiro/2009 & Variação Relativa \\
\hline Exportação & (US\$ mil) 39.534 & (US\$ mil) 58.520 & $-32,44$ \\
\hline Importação & (US\$ mil) 3.019 & (US\$ mil) 198 & $1.424,75$ \\
\hline Saldo & 1.763 toneladas & 76 toneladas & \\
\hline & (US\$ mil) 36.515 & (US\$ mil) 58.322 & \\
\hline
\end{tabular}

Fonte: MDIC (2010) 
ANEXO 5 - Exportações brasileiras de algodão

(principais países importadores - Anual)

\begin{tabular}{|c|c|c|}
\hline Países & Janeiro a Fevereiro/2010 (US\$ mil) & Janeiro a Fevereiro/2009 (US\$ mil) \\
\hline Coréia do Sul & 27.114 & 26.424 \\
\hline Indonésia & 19.953 & 28.579 \\
\hline Tailândia & 7.808 & 7.726 \\
\hline Paquistão & 7.385 & 4.809 \\
\hline China & 4.677 & 4.858 \\
\hline Turquia & 4.362 & 1.001 \\
\hline Argentina & 3.916 & 3.086 \\
\hline Japão & 3.281 & 5.768 \\
\hline Vietnã & 2.764 & 1.232 \\
\hline
\end{tabular}

Fonte: MDIC (2010) 
ANEXO 6 - Importações brasileiras de algodão

(principais países exportadores - Anual)

\begin{tabular}{|c|c|c|}
\hline Países & Janeiro a Fevereiro/2010 (US\$ mil) & Janeiro a Fevereiro/2009 (US\$ mil) \\
\hline $\begin{array}{c}\text { Estados } \\
\text { Unidos }\end{array}$ & 2.842 & \\
\hline Paraguai & 2.659 & \\
\hline Egito & 127 & 472 \\
\hline Israel & 54 & \\
\hline Turquia & & \\
\hline
\end{tabular}

Fonte: MDIC (2010) 